\title{
Forebrain Deletion of the Vesicular Acetylcholine Transporter Results in Deficits in Executive Function, Metabolic, and RNA Splicing Abnormalities in the Prefrontal Cortex
}

\author{
Benjamin Kolisnyk, ${ }^{1,2}$ Mohammed A. Al-Onaizi, ${ }^{1,4}$ Pedro H. F. Hirata, ${ }^{1}$ Monica S. Guzman, ${ }^{1,3}$ Simona Nikolova, ${ }^{1}$ \\ Shahar Barbash, ${ }^{6}$ Hermona Soreq, ${ }^{6}$ Robert Bartha, ${ }^{1,5}$ Marco A. M. Prado, ${ }^{1,2,3,4}$ and Vania F. Prado ${ }^{1,2,3,4}$ \\ ${ }^{1}$ Robarts Research Institute, ${ }^{2}$ Graduate Program in Neuroscience, ${ }^{3}$ Department of Physiology and Pharmacology, ${ }^{4}$ Department of Anatomy and Cell \\ Biology, ${ }^{5}$ Department of Medical Biophysics, Schulich School of Medicine and Dentistry, University of Western Ontario, London, Ontario, Canada, N6A \\ 5K8, and ${ }^{6}$ Department of Biological Chemistry and The Edmond and Lily Safra Center of Brain Science, The Hebrew University of Jerusalem, Jerusalem \\ 91904, Israel
}

One of the key brain regions in cognitive processing and executive function is the prefrontal cortex (PFC), which receives cholinergic input from basal forebrain cholinergic neurons. We evaluated the contribution of synaptically released acetylcholine (ACh) to executive function by genetically targeting the vesicular acetylcholine transporter (VAChT) in the mouse forebrain. Executive function was assessed using a pairwise visual discrimination paradigm and the 5-choice serial reaction time task (5-CSRT). In the pairwise test, VAChTdeficient mice were able to learn, but were impaired in reversal learning, suggesting that these mice present cognitive inflexibility. Interestingly, VAChT-targeted mice took longer to reach criteria in the 5-CSRT. Although their performance was indistinguishable from that of control mice during low attentional demand, increased attentional demand revealed striking deficits in VAChT-deleted mice. Galantamine, a cholinesterase inhibitor used in Alzheimer's disease, significantly improved the performance of control mice, but not of VAChT-deficient mice on the 5-CSRT. In vivo magnetic resonance spectroscopy showed altered levels of two neurochemical markers of neuronal function, taurine and lactate, suggesting altered PFC metabolism in VAChT-deficient mice. The PFC of these mice displayed a drastic reduction in the splicing factor heterogeneous nuclear ribonucleoprotein A2/B1 (hnRNPA2/B1), whose cholinergic-mediated reduction was previously demonstrated in Alzheimer's disease. Consequently, several key hnRNPA2/B1 target transcripts involved in neuronal function present changes in alternative splicing in VAChT-deficient mice, including pyruvate kinase $\mathrm{M}$, a key enzyme involved in lactate metabolism. We propose that VAChT-targeted mice can be used to model and to dissect the neurochemical basis of executive abnormalities.

\section{Introduction}

The prefrontal cortex (PFC) is essential for the modulation of executive function, which is loosely defined as a set of cognitive tools that allows hierarchical and timely control of actions leading to specific behaviors (Alvarez and Emory, 2006; Robbins and Roberts, 2007; Chudasama, 2011). Disruption in executive function is a key symptom in neurological and neuropsychiatric disorders, including Alzheimer's disease (AD; Perry and Hodges,

\footnotetext{
Received May 6, 2013; revised July 29, 2013; accepted Aug. 8, 2013.

Author contributions: B.K., R.B., M.A.M.P., and V.F.P. designed research; B.K., M.A.A.-O., P.H.F.H., M.S.G., and S.N. performed research; S.B. and H.S. contributed unpublished reagents/analytic tools; B.K., M.A.A.-O., P.H.F.H., M.S.G., S.N., S.B., H.S., R.B., M.A.M.P., and V.F.P. analyzed data; B.K., M.A.M.P., and V.F.P. wrote the paper.

This work was supported by Canadian Institutes of Health Research (MOP 89919 and 126000, M.A.M.P. and V.F.P.), Natural Sciences and Engineering Research Council of Canada (V.F.P.), Canadian Foundation for Innovation, and Ontario Research Fund (M.A.M.P., V.F.P.).

The authors declare no competing financial interests.

Correspondence should be addressed to either Marco Prado or Vania Prado, Robarts Research Institute, University of Western Ontario, London, Ontario, Canada, N61 5K8. E-mail: mprado@robarts.ca or vprado@robarts.ca.

DOI:10.1523/JNEUROSCI.1933-13.2013

Copyright $\odot 2013$ the authors $\quad 0270-6474 / 13 / 3314908-13 \$ 15.00 / 0$
}

1999; Traykov et al., 2007; McGuinness et al., 2010), schizophrenia (Morice, 1990), autism (Hill, 2004; Sala et al., 2011), and drug addiction (Stalnaker et al., 2009). The basic neurochemical underpinnings of executive function are, however, still poorly understood.

Cholinergic deficits are a hallmark of AD (Perry et al., 1977; Whitehouse et al., 1981, 1982). Moreover, amyloid $\beta(\mathrm{A} \beta)$ oligomers, potential toxins in $\mathrm{AD}$, disrupt cholinergic synaptic transmission in the PFC (Chen et al., 2013). Cholinergic deficiency in $\mathrm{AD}$ can have widespread effects, including global changes in alternative splicing of genes involved in synaptic plasticity (Berson et al., 2012).

Acetylcholine (ACh) in the PFC has been implicated in controlling attention (Elliott, 2003; Jurado and Rosselli, 2007), one of the components of executive function. Cue detection and topdown modulation of attentive behavior have both been shown to activate PFC cholinergic activity and to be modulated by cholinergic signaling (Sarter et al., 2001; Parikh et al., 2007). Cholinergic transients in the PFC have been linked to cue detection, and 
both tonic and phasic PFC ACh release seem to regulate attentional demand (Parikh et al., 2007; for review, see Hasselmo and Sarter, 2011), which may depend mainly on nicotinic receptor signaling (McGaughy et al., 1999; Grottick and Higgins, 2000; Parikh et al., 2010; Guillem et al., 2011).

Cognitive flexibility, the ability to alter strategy according to changing environmental cues, is another key component of executive function (Elliott, 2003; Jurado and Rosselli, 2007). The neurochemical basis of cognitive flexibility is not fully understood, but serotonin is thought to play critical roles (Schmitt et al., 2006; Evers et al., 2007; Brigman et al., 2010).

Release of ACh is a tightly regulated process, with the vesicular acetylcholine transporter (VAChT) controlling a limiting key step (de Castro et al., 2009a; Kolisnyk et al., 2013; for review, see Prado et al., 2013). Genetic elimination of VAChT from the forebrain causes deficits in reversal learning assessed using the Morris Water Maze (MWM) (Martyn et al., 2012). Deficits in reversal learning may be related to hippocampal dysfunction, but could also reflect alterations in behavioral flexibility. To examine if decreased levels of VAChT, a change observed in $\mathrm{AD}$ (Efange et al., 1997; Chen et al., 2011), affects executive function we have used touchscreen tasks. We report that elimination of forebrain VAChT caused severe deficits in cognitive flexibility and in sustained attention. In addition, we found that these mutant mice have profound changes in RNA processing in the PFC, which correlate with behavioral and metabolic deficits. Our results suggest that elimination of forebrain cholinergic activity in mice provides a model for understanding the neurochemical basis of executive function.

\section{Materials and Methods}

Animals. Generation of VAChT ${ }^{\text {Six3-Cre-flox/flox }}$ mice was previously described (Martyn et al., 2012). In short, VAChT ${ }^{\text {Six3-Cre-flox/flox }}$ mice were generated by crossing VAChT ${ }^{\text {flox/flox }}$ (mixed C57BL/6J $\times 129 / \mathrm{SvEv}$ background, backcrossed to $\mathrm{C} 57 \mathrm{BL} / 6 \mathrm{~J}$ for five generations) with the Six3-Cre mouse line (NMRI background, backcrossed to C57BL/6J for five generations). We then intercrossed $\mathrm{VAChT}^{\mathrm{Six} 3-\mathrm{Cre}-\mathrm{flox} / \mathrm{wt}}$ mice to obtain VAChT ${ }^{\text {Six } 3-C r e-f l o x / f l o x}$. For the galantamine experiments, the mice used were wild-type C57BL/6J. Mice were housed in groups of three or four per cage without environmental enrichment in a temperaturecontrolled room with $14 / 10 \mathrm{~h}$ light/dark cycle, and water was provided ad libitum. Only male mice were used in these studies. Mice were restricted to $85 \%$ of their free-feed weight and maintained on $85 \%$ of their weight for the duration of the study. All procedures were conducted in accordance with guidelines from the Canadian Council of Animal Care at the University of Western Ontario with an approved institutional animal protocol (2008-127).

Western blotting. Mouse PFC was collected, protein was isolated, and immunoblotting was performed as previously described (Martins-Silva et al., 2011). The antibodies used were anti-VAChT (catalog \#139103; Synaptic Systems) at a 1:3000 dilution, anti-Synaptophysin (catalog \#S5768; Sigma-Aldrich) at a 1:500 dilution, anti-hnRNP A2/B1 (catalog \#sc-10035; Santa Cruz Biotechnology) at a 1:500 dilution, and anti- $\beta$ Actin (catalog \#ab49900; Abcam), at a 1:15000 dilution. Band intensity was quantified using FluoroChemQ software (Thermo Fisher Scientific).

ACh release. ACh release from prefrontal cortical brain slices was quantified by labeling slices with $\left[{ }^{3} \mathrm{H}\right]$ methyl-choline before using $\mathrm{KCl}$ to stimulate release of labeled ACh as previously described (Guzman et al., 2011).

qPCR. To measure mRNA expression, total RNA was extracted from freshly dissected PFC tissue, using the Aurum Total RNA for fatty and fibrous tissue kit (Bio-Rad) according to the manufacturer's instructions. cDNA synthesis and qPCR analysis were performed as previously described (Guzman et al., 2011). Primer sequences used to determine alternative spliced transcripts are found in Table 1. $\beta$-Actin was used as a reference transcript for all reactions. For alternative splicing experi-
Table 1. Primers for alternative splicing assay

\begin{tabular}{|c|c|c|}
\hline Target & Forward primer $\left(5^{\prime} \rightarrow 3^{\prime}\right)$ & Reverse primer $\left(5^{\prime} \rightarrow 3^{\prime}\right)$ \\
\hline CD55 exon 8 & CCCAGCATGTACCTGTTACC & TCACATGCAAAACTGTCAAGG \\
\hline CD55 exon 1 & TGTCTCTGTTGCTGCTGTCC & TGCTCAGCAAACTTGGAGTG \\
\hline DRAM2 exon 2 & TGATTCAAGGITCACACTCACA & AAAACTGAGGCCTTGCTGAA \\
\hline DRAM2 exon 4 & TTCAGCAAGGCCTCAGTTTT & TCAGGAGGTATTGTCCCTGTG \\
\hline SIPA1L1 intron 5 & TCAGGCATGCAGTTCTTTTG & GAAAGCAGGCAGTACCTTCG \\
\hline SIPA1L1 exon 4 & TAGTGTGGACGCTGCTGTCT & GGCTCTGTGGTCACCAGAAT \\
\hline DYSTONIN exon 41 & ATGGCATTTCCCCCATTAG & GGAGGTTGGTTTTGCTTCAA \\
\hline DYSTONIN exon 7 & GAGCGGGACAAAGTTCAAAA & CCCGTCCCTCAGATCCTC \\
\hline REELIN exon 3 & ATCATGTCCGACCACCAGTT & ATCATGTCCGACCACCAGTT \\
\hline REELIN exon 18 & GCAGTGCCAGACTTTCCTCT & GCCTCCCATCTTTGTTGAAA \\
\hline REELIN exon 1 & GGCAACCCCACCTACTACG & GACTGGATGCTTGTCGAGGT \\
\hline mENAH & CGGCAGTAAGTCACCTGTCA & С TTCAGCTTTGCCAGCTCTT \\
\hline mENAH invasive & GATTCAAGACCATCAGGTTGTG & CAATGTTGGCCCTAAATAGAA \\
\hline PKM1 & CATGCAGCACCTGATAGCTC & TTATAAGAGGCCTCCACGCTG \\
\hline PKM2 & GCAGTGGGGCCATTATCGT & GGGATTTCGAGTCACGGCAA \\
\hline
\end{tabular}

ments, the alternative exon levels were normalized to a constitutively expressed exon from the same gene.

Magnetic resonance imaging. Magnetic resonance spectroscopy of the prefrontal region was performed in four VAChT ${ }^{\text {Six3-Cre-flox/flox }}$ mice and four littermates $\left(\mathrm{VACh} \mathrm{T}^{\text {flox/flox }}\right.$ ). Spectroscopic localization of a $24 \mu \mathrm{l}$ voxel was achieved by adiabatic selective refocusing (DelaBarre and Garwood, 1998) on a 9.4 tesla horizontal bore small animal Agilent magnetic resonance imaging (MRI) scanner. Water-suppressed full spectra (TR/ $\mathrm{TE}=3250 / 20 \mathrm{~ms}, 128$ acquisitions), water-suppressed macromolecule spectra $(\mathrm{TR} / \mathrm{TE}=5000 / 20 \mathrm{~ms}$, inversion time TI $=873 \mathrm{~ms}, 128$ acquisitions), and water-unsuppressed spectra (TR/TE $=3250 / 20 \mathrm{~ms}, 8 \mathrm{ac}-$ quisitions) were acquired. All animals were anesthetized with $2 \%$ isoflurane during the procedure and were maintained at $37^{\circ}$ by blowing warm air into the bore of the magnet using a Model 1025 Small Animal Monitoring and Gating System (SA Instruments).

Metabolite analysis. Magnetic resonance spectra were analyzed using purpose-built software (fitMAN; Bartha et al., 1999) to determine the contribution of each metabolite relative to total creatine as previously described (Bartha, 2007, 2008). Briefly, spectra were lineshape corrected (Bartha et al., 2000b) and the macromolecule and residual water contribution was removed (Kassem and Bartha, 2003). Then, the spectrum was fitted in the time domain to a basis set of 19 metabolite lineshapes (Pfeuffer et al., 1999; Bartha et al., 2000a). Five metabolites (measured relative to creatine) were reliably measured and included in group comparisons: $\mathrm{N}$-acetylaspartate (NAA), myo-inositol (Myo), choline (Cho), taurine (Tau), and lactate (Lac).

\section{Touchscreen behavioral assessment}

Apparatus and task. Mice were trained in the 5-choice serial reaction time task (5-CSRT) and in the pairwise visual discrimination in automated Bussey-Saksida Mouse Touchscreen Systems model 81426 (Campden Instruments). Schedules were designed and data were collected using the ABET II Touch software v.2.15 (Lafayette Instruments).

Pretraining. Before being trained on the pairwise visual discrimination or the 5-CSRT task, mice were first put through a pretraining program. This consisted of first habituating the mice to the testing chamber with the lights off for $15 \mathrm{~min}$. The next day, mice were left in the chamber with the lights off for $20 \mathrm{~min}$, this time with the reward tray primed with a 150 $\mu l$ reward (strawberry milkshake; Saputo Dairy Products), and a tone was played whenever the mouse entered the reward tray. Whenever the mouse returned to the reward tray, it received a reward $(7 \mu \mathrm{l})$ paired with the tone. This training was repeated the next $2 \mathrm{~d}$ for $40 \mathrm{~min}$ sessions (phase 1).

The next training phase (phase 2) involved pairing the reward with the presentation of the stimulus on the touchscreen. The stimulus appeared randomly in one of the windows and after $30 \mathrm{~s}$, it was removed and a reward $(7 \mu \mathrm{l})$ was given paired with a tone. If the mouse touched the screen while the image was displayed, it immediately received a reward (7 $\mu \mathrm{l})$. Once the mouse collected the reward a new trial was initiated. This 
phase was repeated until the mouse completed 30 trials within 60 min (phase 2).

Phase 3 was used to further shape behavior. It involved displaying the stimulus randomly in one of the windows. The mouse was required to touch the stimulus on the screen to receive a reward $(7 \mu \mathrm{l})$ paired with a tone. There was no response to the mouse touching anything but the stimulus. Once again, this was repeated until the mouse completed 30 trials within $60 \mathrm{~min}$. Phase 4 was identical to phase 3 except that the mouse was required to initiate each trial by nose poking the reward tray. Criterion was 30 correct trials within $60 \mathrm{~min}$.

Finally, in the last pretraining phase (phase 5 ), the previous procedure was repeated but if the mouse touched an incorrect screen, it received a $5 \mathrm{~s}$ time-out, during which the light was turned on. The final phase had a stricter criterion, requiring the mouse to perform 30 trials in $60 \mathrm{~min}$ with at least 23 correct responses in 2 consecutive days.

Pairwise visual discrimination and reversal. Pairwise visual discrimination and reversal task were performed as previously described (Romberg et al., 2013). Mice used in this experiment were 6-8 months old. At the beginning of each session, the reward tray was primed with $7 \mu \mathrm{l}$ of milkshake. Briefly, the mice were first trained to discriminate between two visual stimuli, which were presented simultaneously, with their spatial location randomized over a 30 trial session. If mouse nose poked the correct stimulus $(\mathrm{S}+)$, a tone was played and mouse received a reward $(7 \mu \mathrm{l})$, whereas if the incorrect stimulus $(\mathrm{S}-$ ) was nose poked, light in the chamber was turned on for $5 \mathrm{~s}$ (timeout) followed by a correction trial. During the correction trial, the trial was repeated until the mouse poked the correct stimulus. Criterion was reached when the mouse selected the correct image $(\mathrm{S}+)$ on $80 \%$ of the trials, excluding correction trials, for 2 consecutive days. Once mice reached criteria, they were given two sessions to assess baseline performance on the task. For reversal learning the rule associated to each stimulus was switched, that is, the rewarded image $(\mathrm{S}+)$ during acquisition became the $(\mathrm{S}-)$ image in reversal and was punished, while the $(\mathrm{S}-)$ image from acquisition became the correct stimulus and was rewarded. Reversal learning was assessed over the course of 10 sessions.

Training in 5-CSRT. The 5-CSRT task was performed as previously described (Romberg et al., 2011). A distinct cohort of mice (8-10 months old) was trained in the 5-CSRT task. At the beginning of each session, the reward tray was primed with $7 \mu \mathrm{l}$ of milkshake. Each trial was initiated after the mouse nose poked the magazine. In this phase, the stimulus was delivered after a variable 5-10 s delay (delay period), during which the animal was required to attend to the screen. In case the mouse prematurely touched the screen during this delay, the response was recorded as premature and the mouse was punished with a $10 \mathrm{~s}$ time-out. The stimulus duration was initially set to $4 \mathrm{~s}$, followed by a limited holding period of $5 \mathrm{~s}$,

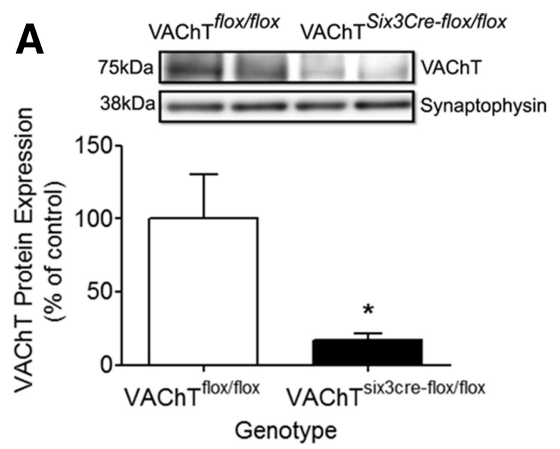

B
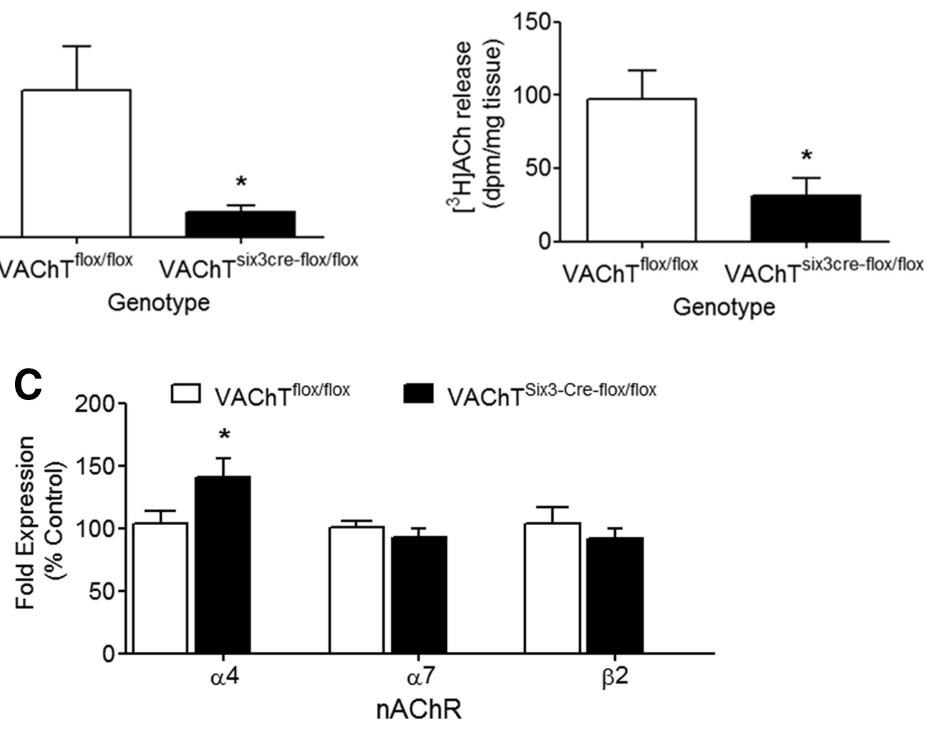

Figure 1. Expression of VAChT in the PFC of VAChT ${ }^{\text {Six } 3-\text { cre-flox/flox }}$ mice. $A$, VAChT protein expression in the PFC with representative immunoblots inset $(n=4)$. B, Release of newly synthesized $\left[{ }^{3} \mathrm{H}\right] \mathrm{ACh}$ in PFC slices $(n=3)$. C, qPCR analysis of nAChR expression $\left(n=6\right.$, data are mean \pm SEM, $\left.{ }^{*} p<0.05\right)$.

\section{A}

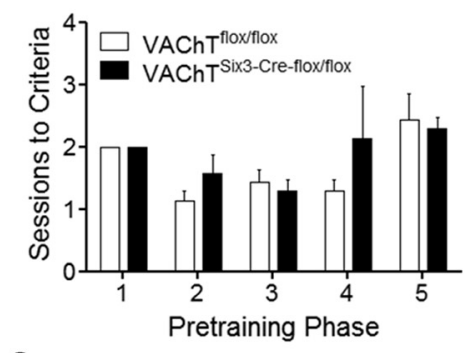

C
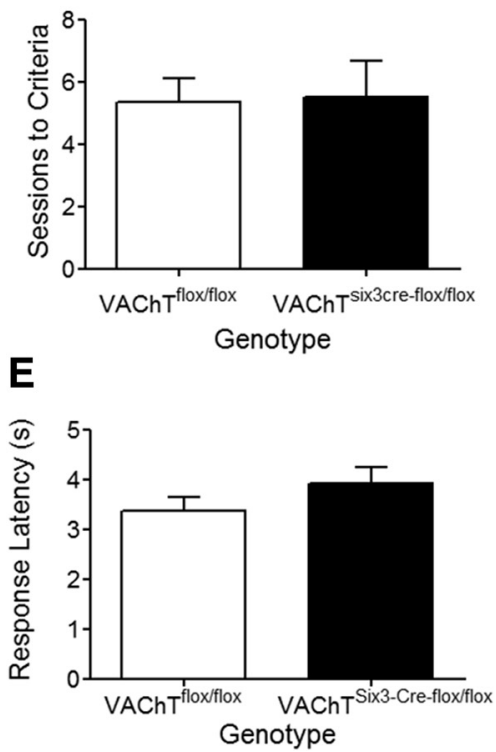

B

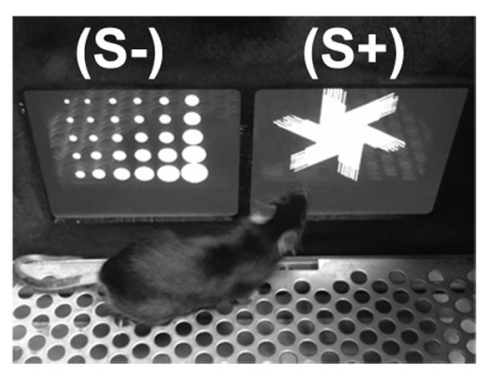

D

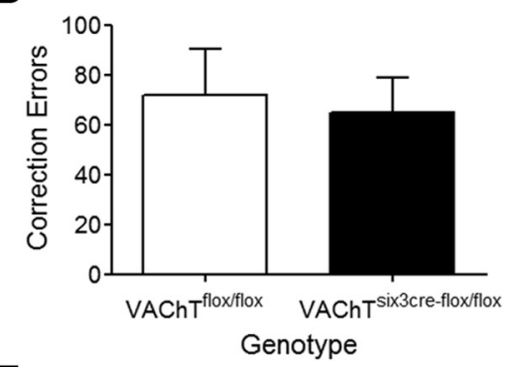

$\mathbf{F}$ क्ञ

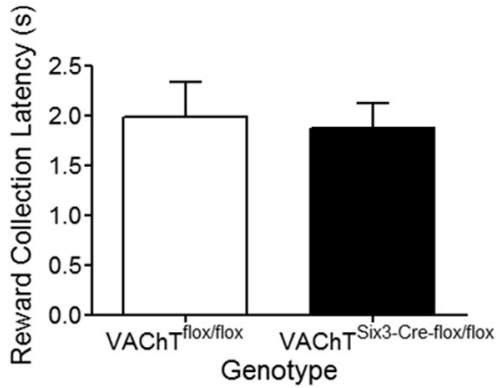

Figure 2. $V A C h T^{\text {Sixz-Cre-flox/flox }}$ mice show normal visual discrimination learning. $A$, Mean number of trials required to reach criteria during the operant conditioning, pretraining phases. $\boldsymbol{B}$, Image of a mouse performing the task, with the fan shown as the $S+$ and the marbles as the $S-$. C, Number of sessions to criteria in the pairwise visual discrimination learning task. $D$, Correction errors made to achieve discrimination criteria. $\boldsymbol{E}$, Mean response latency. $\boldsymbol{F}$, Mean reward collection latency. $n=8$, data are mean \pm SEM. 


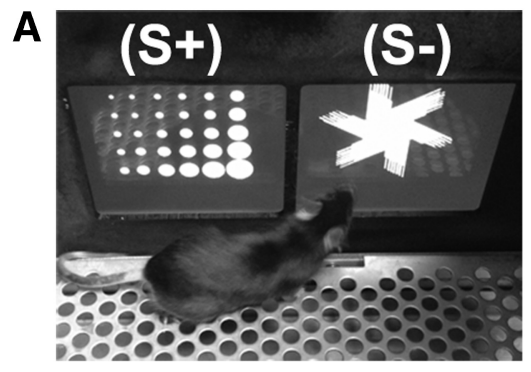

B

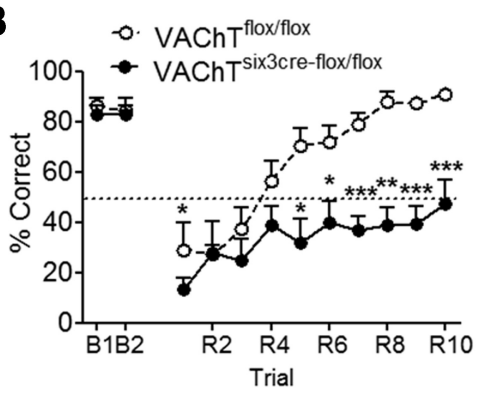

C

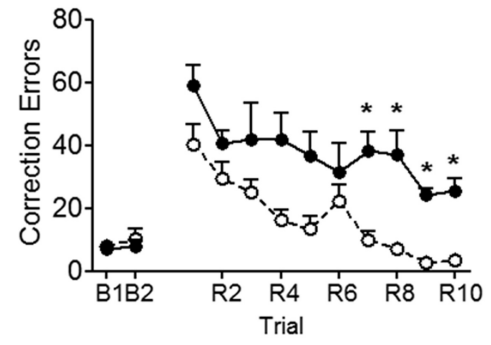

D

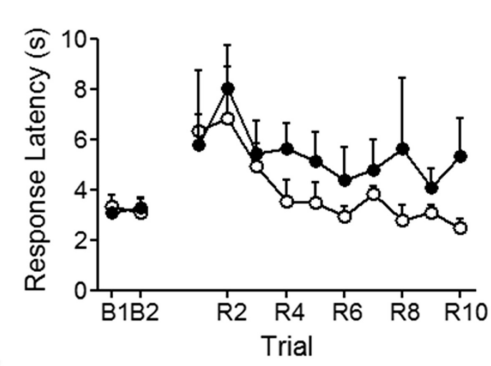

E

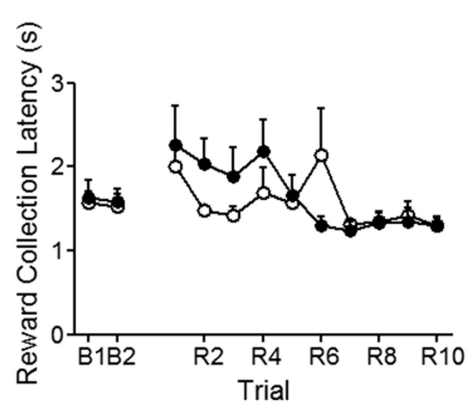

Figure 3. VAChT ${ }^{\text {Sixz-Cre-flox/flox }}$ mice have impaired reversal learning. $A$, Image of a mouse performing the task, this time with the fan shown as the $S-$ and the marbles as the $S+$. $B$, Choice accuracy before (B1 and B2) and during reversal trials (R2-R10), dashed line denotes chance (50\%). C, Number of correction errors made across reversal trials. $\boldsymbol{D}$, Response latency across reversal trials. $\boldsymbol{E}$, Reward collection latency across reversal trials $\left(n=8\right.$, data are mean $\pm \mathrm{SEM}{ }^{*} p<0.05,{ }^{* *} p<0.01$, and $\left.{ }^{* * *} p<0.001\right)$.

during which the stimulus was absent, but the mouse could still respond to the location (holding period). Responses to the stimulus window during stimulus presence or the holding period were recorded as correct and a $7 \mu \mathrm{l}$ reward was administered, while responses to any other window were recorded as incorrect. A correct choice was rewarded with a tone and food delivery. An incorrect response was punished with a $10 \mathrm{~s}$ timeout. A failure to respond to any window either during stimulus display, or during the holding period, was recorded as an omission and punished with a $10 \mathrm{~s}$ time-out. Perseverative responses to the screen after premature, correct, and incorrect choices were also recorded. Once the performance of a mouse reached criterion at $4 \mathrm{~s}$ stimulus duration $(80 \%$ accuracy, $20 \%$ omissions for 3 consecutive days), the stimulus duration was reduced to $2 \mathrm{~s}$. After reaching criterion with the $2 \mathrm{~s}$ stimulus, mice were tested for two more days. The mean measurement of those $2 \mathrm{~d}$ was used to assess baseline performance. If the mouse completed $<30$ trials, it was considered not to have reached criteria, even if it met accuracy and omissions thresholds.

Probe trial. To probe attention in mice we used a previously described probe trial schedule with reduced stimulus durations (Romberg et al., 2011). Briefly, each mouse was tested for 2 consecutive days at a given stimulus duration $(1.5,1,0.8$, and $0.6 \mathrm{~s})$. After each test, the animal was retested onto the $2 \mathrm{~s}$ stimulus duration for $2 \mathrm{~d}$ or until criteria were reached ( $80 \%$ accuracy, $20 \%$ omission), to assess baseline performance. The order of the probe trial sessions were semirandomized using a Latin square method.

Distraction task. To further test attentional demand, and assess susceptibility to distraction, we developed a distraction version of the 5-CSRT task. During this task, a $1000 \mathrm{~ms}$ distractor tone, different from the reward tone, was played semirandomly at five different time points during the delay period: 0 (corresponding to when the mouse initiates the task), $0.5,2.5,4.5$, and $5 \mathrm{~s}$ (corresponding to when the stimulus is displayed on the touchscreens). Stimulus duration was set to $2 \mathrm{~s}$. For each distractor tone time point mice were tested for five sessions. At the end of the five sessions one baseline task ( 50 trial, $2 \mathrm{~s}$ stimulus duration, no distractor sounds) was performed before moving to the next distractor time point.

5-CSRT task measures. On all 5-CSRT task sessions, accuracy was defined as the total number of correct responses, divided by the number of correct and incorrect (touches to a wrong window while the correct stimulus was still displayed) responses. The rate of omissions was the proportion of omitted responses to total trials. Response latency was the time for the mouse to touch the correct stimulus after its onset. Reward collection latency was the time for the mouse to return to the reward tray once it had touched the correct stimulus. A premature response was counted when the mouse touched one of the windows before stimulus onset. Finally, a perseverative response was any identical response that occurred following a correct, incorrect, or premature response.

Drug treatment. Galantamine hydrobromide, a cholinesterase inhibitor, (SigmaAldrich) was dissolved in physiological saline $(0.9 \% \mathrm{NaCl})$ before administration. Sixty minutes before being tested on the 5-CSRT mice received an intraperitoneal injection of drug (100 $\mu \mathrm{l}, 1 \mathrm{mg} / \mathrm{kg}$ ) or saline. The dose for galantamine was selected based on previous studies (Prado et al., 2006; de Castro et al., 2009b; De Jaeger et al., 2013). Previously, we have tested 3 $\mathrm{mg} / \mathrm{kg}$ galantamine in other tasks, but this dose was no more effective than $1 \mathrm{mg} / \mathrm{kg}$ and it produced hypersalivation in mice (de Castro et al., $2009 \mathrm{~b}$ ). Moreover, at $1 \mathrm{mg} / \mathrm{kg}$ wild-type mice were able to increase their performance in the 5-CSRT (see below). Mice were tested at the $0.6 \mathrm{~s}$ stimulus duration, which represents a high attention demanding task (Romberg et al., 2011). The order of the injections was counterbalanced. Between injections mice had three washout days wherein their performance on the 5CSRT was re-baselined at the $2 \mathrm{~s}$ stimulus duration.

Statistical analysis. For the pairwise visual discrimination task response accuracy was calculated as the number of correct trials divided by the total number of trials, excluding correction trials. Data are expressed as mean \pm SEM. SigmaStat 3.5 software was used for statistical analysis. Comparison between two experimental groups was made by Student's $t$ test or Mann-Whitney rank sum test, when the data did not follow a normal distribution. When several experimental groups or treatments were analyzed, two-way ANOVA or two-way ANOVA with repeated measures was used as required. When appropriate, a Tukey's HSD post hoc comparison test was used. In all comparisons, $p<0.05$ was considered statistically significant.

\section{Results}

VAChT ${ }^{\text {Six3-Cre-flox/flox }}$ mice have reduced VAChT and ACh

release in the PFC

We have previously reported that $\mathrm{VAChT}^{\mathrm{Six} 3 \text {-Cre-flox/flox }}$ mice have the VAChT gene deleted from $>90 \%$ of their basal forebrain cholinergic neurons (Martyn et al., 2012). To confirm that this deletion affected prefrontal cortical cholinergic signaling, we per- 
formed Western blot analysis to assess VAChT expression. $\mathrm{VAChT}^{\text {Six3-Cre-flox/flox }}$ mice have a significant reduction in PFC VAChT protein expression $\left(t_{(6)}=2.706, p=0.0353\right.$; Fig. $1 A$ ). Moreover, this reduction in VAChT protein levels results in a significant decrease in newly synthesized $\left[{ }^{3} \mathrm{H}\right]$ ACh release in slices of PFC from VAChT ${ }^{\text {Six3-Cre-flox/flox }}$ mice when compared with control mice $\left(t_{(4)}=2.899, p=0.0442\right.$; Fig. $\left.1 B\right)$. We used qPCR to assess the expression of nicotinic receptors (nAChRs), which have been shown previously to be critical for attentional performance. The PFC of VAChT ${ }^{\text {Six3-Cre-flox/flox }}$ mice shows no significant change in the expression of $\alpha 7 \mathrm{nAChR}$ mRNA $\left(t_{(10)}=\right.$ $0.9300, p=0.3743)$ nor $\beta 2 \mathrm{nAChR}$ mRNA $\left(t_{(10)}=0.8359, p=\right.$ $0.4227)$. Interestingly, $\alpha 4 \mathrm{nAChR}$ mRNA is slightly upregulated $\left(t_{(10)}=2.550, p=0.0289\right.$; Fig. $\left.1 C\right)$.

\section{Decreased forebrain cholinergic tone specifically disturbs} reversal learning in the pairwise visual discrimination task. We have previously demonstrated that VAChT ${ }^{\text {Six } 3-C r e-f l o x / f l o x ~}$ mice have impairments in reversal learning in the MWM (Martyn et al., 2012), suggesting the possibility that these mice have behavior flexibility deficits. To determine whether $\mathrm{VAChT}^{\text {Six3-Cre-flox/flox }}$ mice present alterations in cognitive flexibility we used a "nonhippocampal" pairwise visual discrimination task (Romberg et al., 2013). This task has been previously shown to depend on the PFC and also on striatal-cortical loops (Graybeal et al., 2011). The performance of VAChT ${ }^{\text {Six3-Cre-flox/flox }}$ mice did not differ from that of controls (VAChT flox/flox $)$ when they were trained to operate the touchscreen (pretraining phase). The number of sessions the mice took to acquire each training phase did not differ from control (RM-ANOVA, no effect of genotype $F_{(1,54)}=0.3950, p=0.5398$; main effect of training phase $F_{(4,54)}=5.227, p=0.0012$; and no interaction effect $F_{(4,54)}=$ $1.389, p=0.2495$; Figure $2 A$ ). Acquisition of the pairwise visual discrimination task (Fig. 2B; for stimuli used) did not differ between genotypes, in terms of sessions to criteria (Fig. $2 C ; t_{(14)}=$ 0.2446, $p=0.8117$ ), correction errors made (Fig. $2 D ; t_{(14)}=$ $0.2942, p=0.7746$ ), response latency (Fig. $2 E ; t_{(14)}=1.019$, $p=0.3256$ ), or reward collection latency (Fig. $2 F ; t_{(14)}=0.2606$, $p=0.7988)$. We have previously reported that these mice are hyperactive in novel environments, but they are able to habituate to the environment (Martyn et al., 2012). Hence, due to the extensive training for the performance in the touchscreen tasks the lack of differences in response and reward collection latencies is not surprising. However, VAChT ${ }^{\text {Six3-Cre-flox/flox }}$ mice showed severe reversal learning impairment (Fig. 3A; for the stimuli used), measured by the percentage of correct responses (Fig. $3 B$; RMANOVA, main effect of genotype $F_{(1,132)}=19.78, p=0.0008$; main effect of session $F_{(11,132)}=23.28, p=0.0001$; and significant interaction effect $\left.F_{(1,12)}=5.035, p=0.0001\right)$ and by its increased correction errors (Fig. 3C; RM-ANOVA, main effect of genotype $F_{(1,132)}=14.72, p=0.0024$; main effect of session $F_{(11,132)}=14.37, p=0.0001$; and significant interaction effect $\left.F_{(1,12)}=2.817, p=0.0025\right)$. Post hoc analysis showed that VAChT $^{\text {Six3-Cre-flox/flox }}$ mice never improved significantly from the first reversal session and in 10 sessions they performed only at chance level. Importantly, during the reversal trials, the $\mathrm{VAChT}^{\text {Six3-Cre-flox/flox }}$ mice did not differ from controls in terms of response latency (Fig. 3D; RM-ANOVA, no effect of genotype $F_{(1,154)}=0.4233, p=0.5258$; main effect of session $F_{(11,154)}=$ $4.705, p=0.0001$; and no interaction effect $F_{(11,154)}=0.9997, p=$ 0.4493 ) or reward collection latency (Fig. 3E; RM-ANOVA, no effect of genotype $F_{(1,154)}=1.107, p=0.3105$; main effect of session $F_{(11,132)}=3.965, p=0.0001$; and no interaction effect
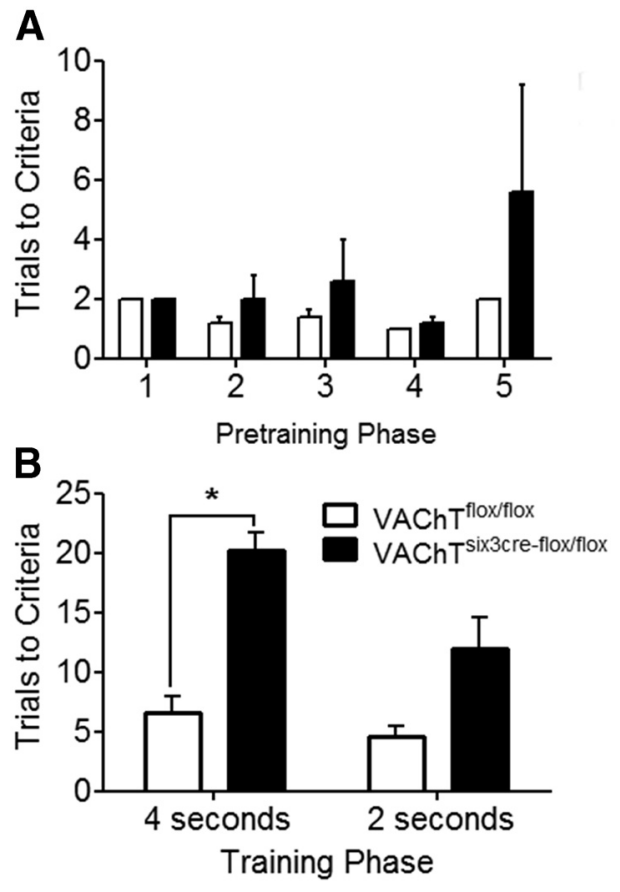

Figure 4. Training in the 5-CSRT task. $\boldsymbol{A}$, Mean number of trials required to reach criteria during the operant conditioning, pretraining phases. $\boldsymbol{B}$, Mean number of trials required to reach criteria at 4 and $2 s$ stimulus duration $\left(n=6\right.$, data are mean \pm SEM, ${ }^{*} p<0.05$ ).

$\left.F_{(11,154)}=1.141, p=0.3333\right)$. These results suggest that forebrain cholinergic tone is important for cognitive flexibility.

\section{VAChT ${ }^{\text {Six3-Cre-flox/flox }}$ mice have impaired acquisition of the 5-CSRT task}

Similar to the results for visual discrimination experiments, the performance of the second cohort of VAChT ${ }^{\text {Six } 3-C r e-f l o x / f l o x}$ mice did not differ from that of control mice for touchscreen operation training (pretraining phase). The number of sessions necessary to reach criteria across all pretraining phases did not differ between genotypes (RM-ANOVA, no effect of genotype $F_{(1,32)}=1.528$, $p=0.2515$; no effect of training phase $F_{(4,32)}=1.492, p=0.2280$; Figure $4 A$ ). However, when mice were trained to respond to flashes of light displayed in one of the five spatial locations on the touchscreen (training phase), VAChT ${ }^{\text {Six3-Cre-flox/flox }}$ showed a significantly worse performance, needing more sessions to reach criteria (RM-ANOVA, main effect of genotype, $F_{(1,8)}=10.06$, $p=0.0132$; main effect of stimulus duration, $F_{(1,8)}=5.731, p=$ 0.0436 , no interaction effect, $F_{(1,8)}=4.252, p=0.0731$; Fig. $4 B$ ).

\section{Deletion of forebrain VAChT results in inattentive but not impulsive or compulsive behavior}

Once mice reached criteria they were tested for attentional performance by decreasing stimulus duration to $1.5,1,0.8$, and $0.6 \mathrm{~s}$ as previously described (Romberg et al., 2011). At $1.5 \mathrm{~s}$, $\mathrm{VAChT}^{\text {Six3-Cre-flox/flox }}$ mice were able to perform identically to control mice in both accuracy and omissions (Fig. 5A,B). In contrast, increasing attentional demand by diminishing the stimuli period revealed an attentional deficit in VAChT ${ }^{\text {Six3-Cre-flox/flox }}$ mice. Response accuracy did not differ between genotypes (RMANOVA, no effect of genotype $F_{(1,24)}=0.0007548, p=0.9788$; main effect of stimulus duration $F_{(3,24)}=10.28, p<0.001$; Figure $5 A$ ). However, VAChT ${ }^{\text {Six3-Cre-flox/flox }}$ mice presented an increased rate of omission (RM-ANOVA, main effect of genotype $F_{(1,24)}=57.99, p<0.0001$; main effect of stimulus duration 


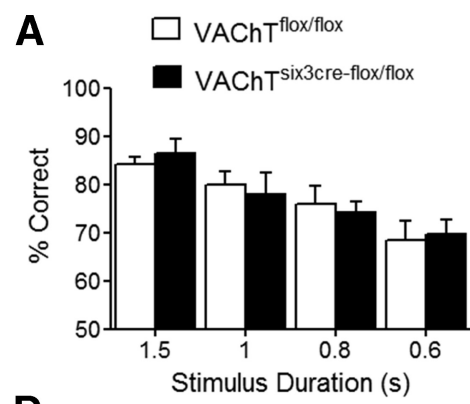

D

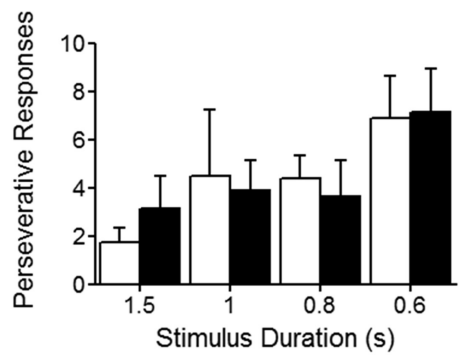

B

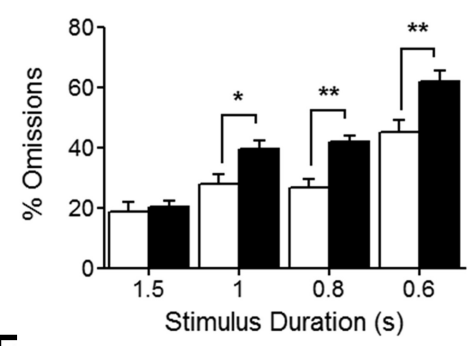

E

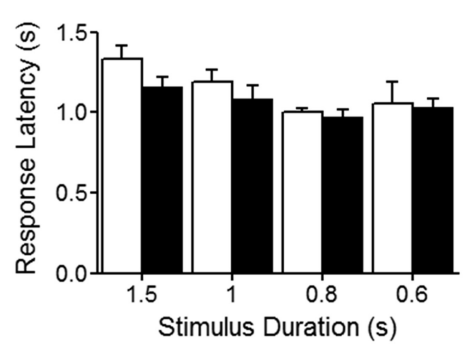

C

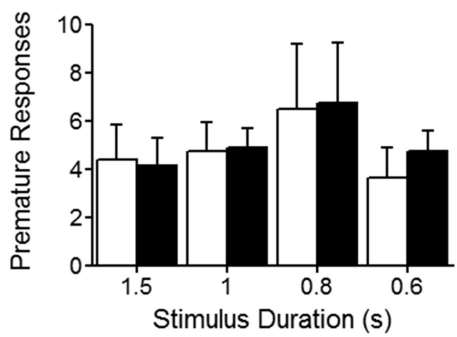

$\mathbf{F}$

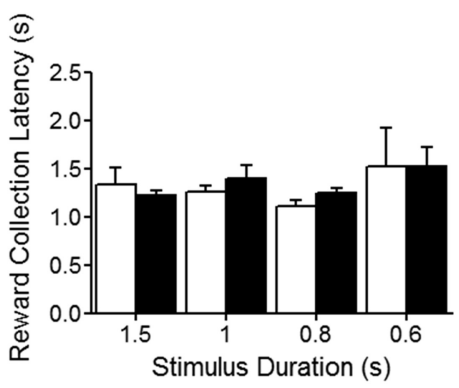

Figure 5. VAChT ${ }^{\text {Six3-Cre-floxfflox }}$ mice have attentional deficits. Performance and response measures during 5-CSRT task probe trials. Mice were subjected to a series of probe trials and the average values of 50 trial sessions are plotted. $\boldsymbol{A}$, Mean accuracy. $\boldsymbol{B}$, Mean rate of omissions. $\boldsymbol{C}$, Mean premature responses. $\boldsymbol{D}$, Mean perseverative responses. $\boldsymbol{E}$, Mean response latency. $\boldsymbol{F}$, Mean reward collection latency $\left(n=6\right.$, data are mean $\pm \mathrm{SEM}^{*}{ }^{*} p 0.05$ and $\left.{ }^{* *} p<0.01\right)$.

A

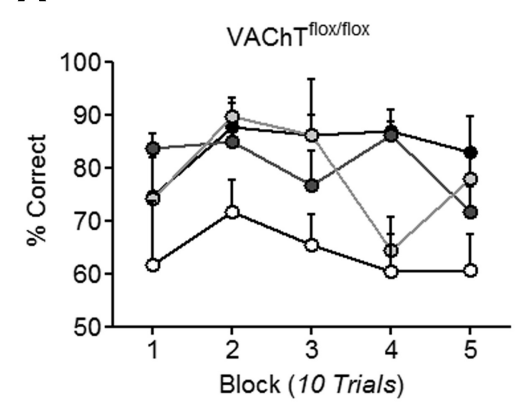

C

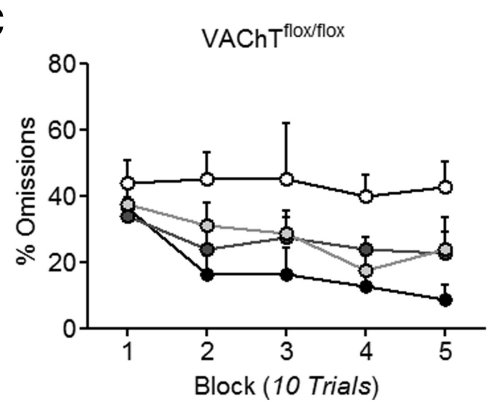

B

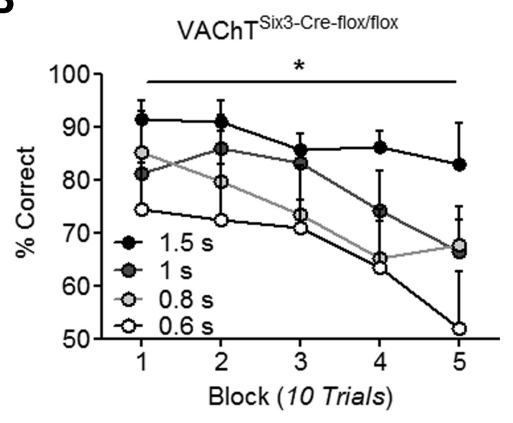

D

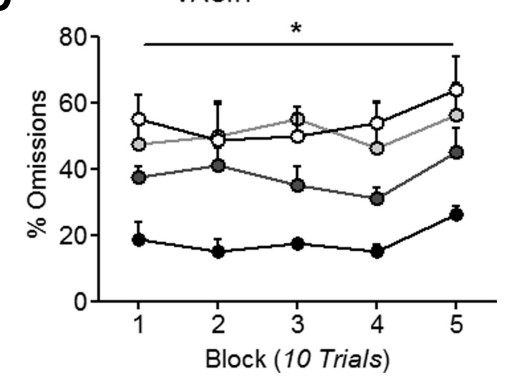

Figure 6. VAChT ${ }^{\text {Six3-Cre-flox/flox }}$ mice have impaired sustained attention. Mean response accuracy for blocks of 10 trials for $(\boldsymbol{A})$ $\mathrm{VAChT}^{\text {flox/flox }}$ and $(\boldsymbol{B}) \mathrm{VAChT}^{\text {Sixz-Cre-flox/flox }}$ mice. Mean rate of omission for blocks of 10 trials for $(\boldsymbol{C}) \mathrm{VAChT}^{\text {flox/flox }}$ and (D) $\mathrm{VAChT}^{\text {Six3-Cre-flox/flox }}$ mice $\left(n=6\right.$, data are mean \pm SEM, $\left.{ }^{*} p<0.05\right)$.

$F_{(3,24)}=36.44, p<0.0001$; no interaction effect $F_{(3,24)}=2.176$, $p=0.1171$; Figure 5B). Post hoc analysis revealed that VAChT $^{\text {Six3-Cre-flox/flox }}$ mice omitted more at 0.6-1 s stimulus durations. Interestingly, VAChT-deficient mice had no alterations in premature responses (RM-ANOVA, no effect of genotype $F_{(1,24)}=0.07440, p=0.7874$; no effect of stimulus duration $F_{(3,24)}=0.9891, p=0.4146$; Figure $5 C$ ) or perseverative responses (RM-ANOVA, no effect of genotype $F_{(1,24)}=0.04610$, $p=0.9695$; no effect of stimulus duration $F_{(3,24)}=1.244, p=$ 0.3232 ; Figure $5 D$ ). Additionally, mutant mice did not differ from littermate controls in response latency (RM-ANOVA, no effect of genotype $F_{(1,24)}=2.279, p=0.1818$; no effect of stimulus duration $F_{(3,24)}=0.09686, p=$ 0.7662 ; Figure $5 E$ ) and reward collection latency (RM-ANOVA, no effect of genotype $F_{(1,24)}=2.279, p=0.1818$; no effect of stimulus duration $F_{(3,24)}=1.189, p=$ 0.3420; Figure 5F).

\section{Deletion of forebrain VAChT impairs sustained attention}

To assess sustained attention (vigilance), we analyzed both response accuracy and rate of omissions over blocks of 10 trials (Romberg et al., 2011). Response accuracy of control mice did not significantly vary across blocks, but did reduce significantly with decreases in stimuli duration (RM-ANOVA, main effect of stimulus duration $F_{(3,48)}=$ 5.893, $p=0.0104$; no effect of block $F_{(4,48)}=1.214, p=0.317$; Figure $\left.6 A\right)$. In contrast, response accuracy of VAChT $^{\text {Six3-Cre-flox/flox }}$ mice reduced significantly across blocks and stimuli duration (RM-ANOVA, main effect of stimulus duration $F_{(3,48)}=4.257, p=0.0077$; main effect of block $F_{(4,48)}=3.933, p=0.0289$; Figure $\left.6 B\right)$. As with response accuracy, rate of omissions of control mice did not vary across blocks, only with stimuli duration (RM-ANOVA, main effect of stimulus duration $F_{(3,48)}=5.803, p=0.0228$; no effect of block $F_{(4,48)}=0.5352, p=0.7105$; Figure $\left.6 C\right)$, whereas rate of omissions of $\mathrm{VAChT}^{\text {Six3-Cre-flox/flox }}$ mice increased significantly across stimuli duration and blocks (RM-ANOVA, main effect of stimulus duration $F_{(3,48)}=9.387, p=0.0018$; main 
effect of block $F_{(4,48)}=2.803, p=$ 0.0360; Figure 6D). Together the data suggest that VAChT ${ }^{\text {Six3-Cre-flox/flox }}$ mice have impaired ability to sustain attention.

\section{Deletion of forebrain VAChT increases susceptibility to distractions \\ To assess distractibility of VAChT ${ }^{\text {Six3-Cre-flox/ }}$} flox mice, we increased attentional demand by testing them on a distraction variation of the 5-CSRT. Stimulus duration was set to $2 \mathrm{~s}$, where performance of both genotypes was identical, and distractor sounds were played at set time points during trials. Response accuracy of VAChT ${ }^{\text {Six3-Cre-flox/flox }}$ mice tended to be reduced by distractions compared with controls (RM-ANOVA, near significant effect of genotype $F_{(1,32)}=$ 4.825, $p=0.0589$; main effect of distractor onset $F_{(4,32)}=3.583, p=0.0159$; Figure $7 A)$. Rate of omission was significantly higher in VAChT ${ }^{\text {Six3-Cre-flox/flox }}$ mice than controls (RM-ANOVA, significant effect of genotype $F_{(1,32)}=6.809, p=0.0312$; no effect of distractor onset $F_{(4,32)}=2.564, p=$ 0.0572; Figure $7 B$ ). Importantly, neither response latency (RM-ANOVA, no effect of genotype $F_{(1,32)}=1.045, p=0.3367$; main effect of distractor onset $F_{(4,32)}=7.069, p=$ 0.0003 ; Figure $7 C$ ) nor reward collection latency varied between genotypes (RM-ANOVA, no effect of genotype $F_{(1,32)}=0.7467, p=$ 0.4127 ; main effect of distractor onset $F_{(4,32)}=3.226, p=0.0248$; Figure 7D).

\section{Galantamine improves attention in wild-type mice on a demanding task}

Detection of pro-attentive effects of pharmacological manipulations on the 5-CSRT is hampered by possible ceiling effects (Robbins, 2002). To detect differences in mice it is important to test the drug on challenging conditions, which can be achieved by shortening the duration of the stimulus presentation (Romberg et al., 2011). To find a suitably challenging task in which we could observe increased attention, we trained a group $(n=8)$ of wildtype mice on the 5-CSRT, and ran them through the probe trial series, serially reducing stimulus duration $(1.5,1,0.8$, and $0.6 \mathrm{~s})$. Choice accuracy $\left(F_{(4,31)}=13.77, p<0.0001\right.$; Fig. $\left.8 A\right)$ and rate of omissions $\left(F_{(4,31)}=6.716, p=0.0024\right.$; Fig. $\left.8 B\right)$ were significantly affected by reducing stimulus duration. Post hoc analysis revealed that at $0.6 \mathrm{~s}$ stimulus duration the rate of accuracy was significantly reduced, and omissions significantly increased from the $1.5 \mathrm{~s}$ stimulus duration. We therefore chose both, $0.8 \mathrm{~s}$ stimulus duration and the more challenging $0.6 \mathrm{~s}$ stimulus duration, for pharmacological testing. Administration of galantamine $(1 \mathrm{mg} /$ $\mathrm{kg}$, i.p.) $1 \mathrm{~h}$ before 5-CSRT testing at $0.8 \mathrm{~s}$ did not improve accuracy (paired $t$ test, $t_{(7)}=1.287, p=0.2544$; Fig. $8 C$ ) or omissions (paired $t$ test, $t_{(7)}=0.4581, p=0.6661$; Fig. $8 D$ ). However, when administered before a $0.6 \mathrm{~s}$ stimulus duration session, galantamine $(1 \mathrm{mg} / \mathrm{kg})$ significantly improved accuracy compared with saline (paired $t$ test, $t_{(7)}=2.405, p=0.0471$; Fig. $8 E$ ) and significantly reduced the rate of omission (paired $t$ test, $t_{(7)}=$ $2.379, p=0.0489$; Fig. $8 F$ ). Response latency (paired $t$ test, $t_{(7)}=$ 1.296, $p=0.2360$ ), and reward collection latency (paired $t$ test,
B

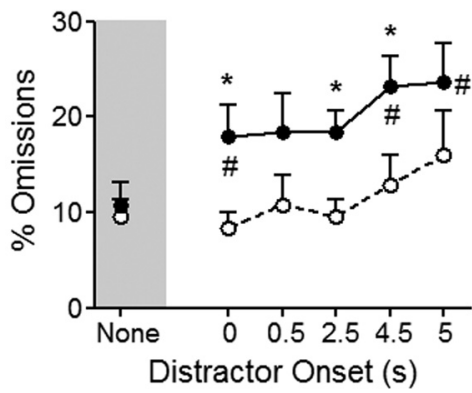

D $\widehat{(n)}$

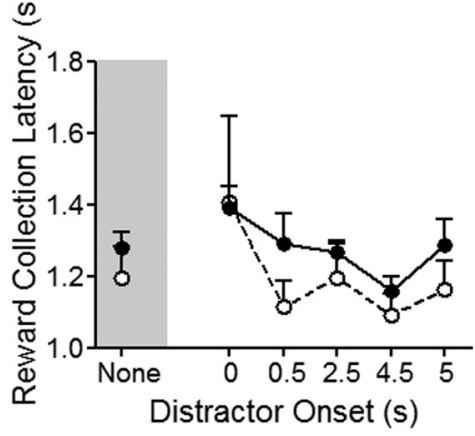

Distractor Onset (s)

Figure 7. VAChT ${ }^{\text {Six3-Cre-flox/flox }}$ mice are more susceptible to distraction. Mice were subjected to a series of distraction trials and the average values of 50 trial sessions per distractor onset are plotted. $\boldsymbol{A}$, Mean response accuracy. $\boldsymbol{B}$, Mean rate of omission. $\boldsymbol{C}$ Mean response latency. $\boldsymbol{D}$, Mean reward collection latency $\left(n=6\right.$, data are mean $\pm S E M,{ }^{*}$ represents significant differences between genotypes, \# represents significant differences within genotypes; ${ }^{*} p<0.05$ ).

$\left.t_{(7)}=0.390, p=0.7080\right)$ were not changed by galantamine injections (data not shown). These results suggest that increased cholinergic tone can increase attentional performance when the probe trial is sufficiently demanding to avoid a potential ceiling effect.

Galantamine does not improve attention deficits in VAChT $^{\text {Six 3-Cre-flox/flox }}$ mice

To investigate if the deficits observed in VAChT $\mathrm{T}^{\text {Six 3-Cre-flox/flox }}$ are exclusively related to decreased levels of synaptic ACh, we injected mice with galantamine ( $1 \mathrm{mg} / \mathrm{Kg} \mathrm{IP})$, a dose that effectively improved performance of wild-type mice (Fig. 8), and tested

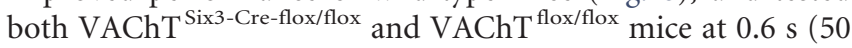
trials). Galantamine tended to improve choice accuracy, albeit this effect did not reach statistical significance (paired $t$ test, $t_{(5)}=$ $1.954, p=0.1224$; Fig. $8 G$ ). However, the drug was able to significantly reduce rate of omissions (paired $t$ test, $t_{(5)}=3.383, p=0.0277$; Fig. $8 H$ ) in VAChT ${ }^{\text {flox/flox }}$ mice. Interestingly, galantamine had no effect on the performance of VAChT ${ }^{\text {Six3-Cre-flox/flox }}$ mice, neither improving accuracy (paired $t$ test, $t_{(5)}=0.162, p=0.880$; Fig. $8 G$ ) nor rate of omission (paired $t$ test, $t_{(5)}=0.868, p=0.434$; Fig. $8 H$ ).

\section{Deletion of forebrain VAChT results in metabolic} abnormalities in the PFC

The lack of effect of galantamine in VAChT ${ }^{\text {Six3-Cre-flox/flox }}$ suggests that diminished ACh release in mutant mice may not be sufficiently increased by galantamine to reverse the attentional deficits in these mice. In addition to that, a chronic decrease in cholinergic tone may cause circuitry or metabolic changes that could affect how neuronal circuitries are recruited for specific cognitive tasks. We used in vivo magnetic resonance spectroscopy to assess if metabolic parameters were affected in the prefrontal region of VAChT-deficient mice (Fig. 9A; representative spectra). 
A

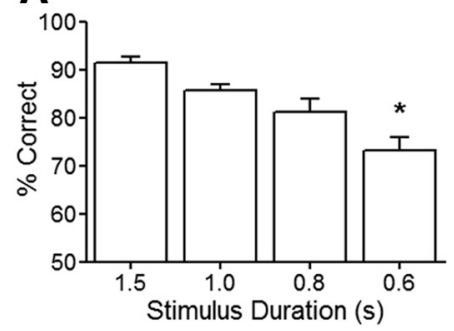

D

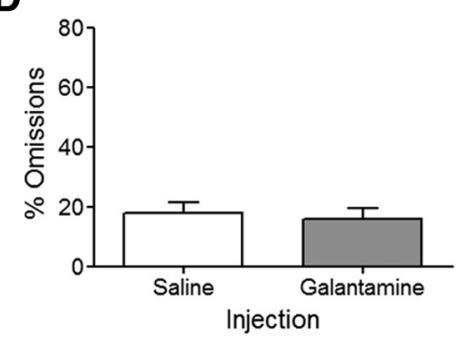

B

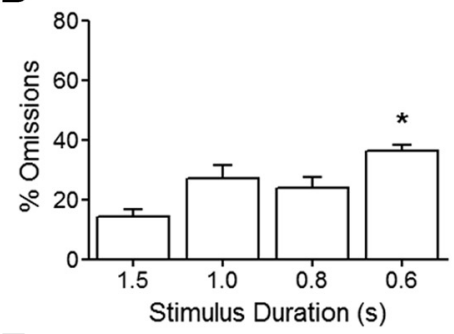

E

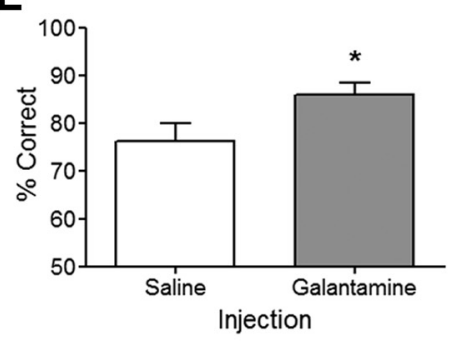

C

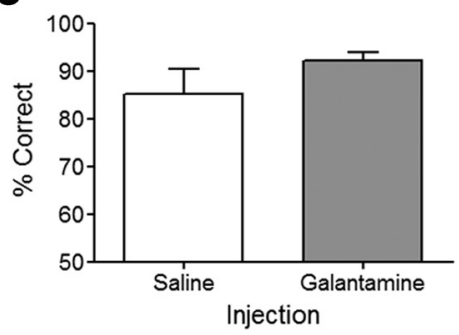

F

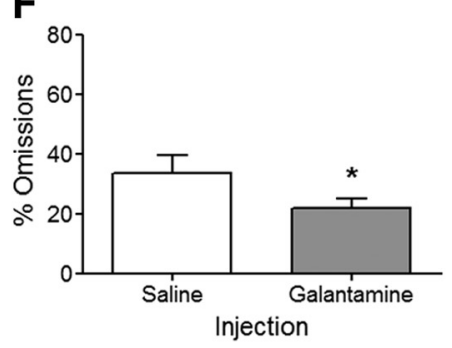

G

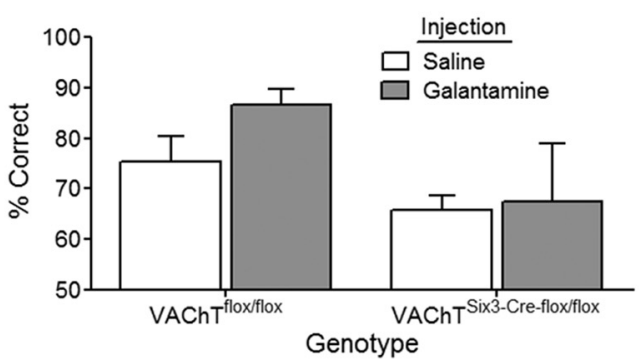

H

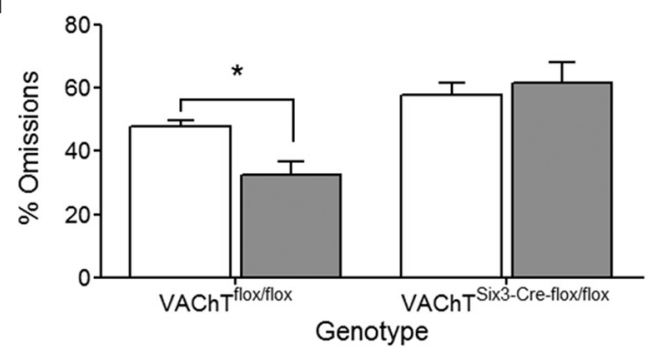

Figure 8. Galantamine improves attention in wild-type, but not in VAChT ${ }^{\text {Six3-Cre-flox/flox }}$ mice. Wild-type mice $(n=8)$ were subjected to a series of probe trials and the average values of 50 trial sessions are plotted. $\boldsymbol{A}$, Mean accuracy. $\boldsymbol{B}$, Mean rate of omissions. Effect of galantamine ( $1 \mathrm{mg} / \mathrm{kg}$ i.p.) on ( $\boldsymbol{C}$ ) response accuracy and (D) rate of omission in wild-type mice at a $0.8 \mathrm{~s} \mathrm{stimulus} \mathrm{duration}$ $(n=8)$. Effect of galantamine on $(\boldsymbol{E})$ response accuracy and $(\boldsymbol{F})$ rate of omission in wild-type mice at a $0.6 \mathrm{~s} \mathrm{stimulus} \mathrm{duration}(n=8)$. Effect of galantamine $(1 \mathrm{mg} / \mathrm{Kg}$ I.P.) on $(\boldsymbol{G})$ choice accuracy and $(\boldsymbol{H})$ rate of omission in VAChT ${ }^{\text {flox/flox }}$ and VAChT ${ }^{\text {Six3-Cre-flox/flox }}$ mice $\left(n=6\right.$, data are mean \pm SEM, $\left.{ }^{*} p<0.05\right)$.

This analysis revealed that VAChT $\mathrm{T}^{\mathrm{Six} 3-\mathrm{Cre}-\text { flox/flox }}$ mice had significantly less Lac $\left(t_{(6)}=2.600, p=0.0428\right.$; Fig. $\left.9 B\right)$ and Tau $\left(t_{(6)}=2.522, p=0.0452\right.$; Fig. $\left.9 C\right)$ than controls. Levels of NAA $\left(t_{(6)}=0.0907, p=0.9307\right.$; Fig. $\left.9 D\right)$, Myo $\left(t_{(6)}=0.9598, p=\right.$ 0.3742; Fig. $9 E)$, and Cho $\left(t_{(6)}=0.1461, p=0.8886\right.$; Fig. $\left.9 F\right)$ remained unchanged.

\section{Deletion of forebrain VAChT results in altered RNA metabolism in the PFC}

Cholinergic deficits in $\mathrm{AD}$ have been proposed to cause major transcriptome changes via aberrant hnRNPA2/B1 expression (Berson et al., 2012). hnRNPA2/B1 refers to a family of proteins that functions as splicing factors and mRNA chaperones (Hoek et al., 1998; Kamma et al., 1999). This gene family is critical for regulating alternative splicing in numerous genes involved with synaptic plasticity and cognition (Berson et al., 2012). Its expression is severely reduced in Alzheimer brain and appears enhanced in primary mouse neurons under carbachol induction (Berson et al., 2012), suggesting cholinergic regulation of hnRNPA2/B1 proteins. To determine whether the PFC of VAChT ${ }^{\text {Six } 3-C r e-f l o x / f l o x ~}$ shows parallel suppression of the hnRNPA2/B1 proteins, their levels were assessed. Compared with controls, the PFC of VAChT $^{\text {Six3-Cre-flox/flox }}$ mice showed a significant reduction in hnRNPA2/B1 expression (75\% decrease, $t_{(6)}=4.941, p=0.0026$; Fig. 10A). We then used qPCR to assess whether the decrease in hnRNPA2/B1 could have a functional impact on RNA processing in the PFC. We evaluated the alternative splicing of the key genes, SIPA1L1(SIPA), REELIN(RELN), DRAM2, CD55, DYSTONIN
(DST), and ENAH, as manifested by increased exon inclusion tested both in Alzheimer's brain and in mouse brain depleted of its cholinergic neurons by saporin-mediated treatment (Berson et al., 2012). This analysis revealed that VAChT ${ }^{\text {Six } 3-C r e-f l o x / f l o x}$ mice had significant changes in the splicing of these genes in the PFC, with significantly increased inclusion of exon 8 of CD55 $\left(t_{(10)}=2.550, p=0.0289\right)$, exon 41 of DST $\left(t_{(10)}=7.436, p=\right.$ $0.0001)$, exon 18 of RELN $\left(t_{(10)}=3.230, p=0.0090\right)$, and exon 2 of DRAM2 $\left(t_{(10)}=3.990, p=0.0260\right)$. In addition the inv isoform of the ENAH gene was also significantly increased $\left(t_{(10)}=\right.$ $2.522, p=0.0303)$. In contrast, intron 5 of SIPA $\left(t_{(10)}=0.5449, p=\right.$ $0.5978)$ and exon 3 of $\operatorname{RELN}\left(t_{(10)}=2.215, p=0.0511\right)$, which have also been shown to be affected in $\mathrm{AD}$, were unchanged, although we detected a trend for the latter (Fig. 10B).

hnRNPA2/B1 has been shown to regulate the splicing of pyruvate kinase $\mathrm{M}$ (PKM) enzyme, which in turn dictates lactate metabolism (David et al., 2010). Knockdown of hnRNPA2/B1 expression in vitro favors the PKM1 isoform, which leads to reduced levels of Lac, whereas upregulation hnRNPA2/B1 favors the PKM2 isoform and increased Lac levels (Clower et al., 2010; for review, see Chen et al., 2010). To test whether alternative splicing of PKM occurs in VAChT ${ }^{\text {Six3- }}$ Cre-flox/flox mice, we performed qPCR to determine the expression of the PKM1 and PKM2 splice variants. Interestingly the VAChT $^{\text {Six3-Cre-flox/flox }}$ mice showed a significant upregulation of the PKM1 variant $\left(t_{(10)}=4.277, p=0.0016\right)$, and a significant reduction in the PKM2 variant $\left(t_{(10)}=3.073, p=0.0110\right.$; Fig. $10 C)$, effectively changing the ratio between these two enzymes. 


\section{Discussion}

In this report we show that forebrain VAChT knock-out mice present deficits in two domains of executive function, cognitive flexibility and attention. Additionally, VAChT-deficient mice exhibit metabolic deficits in the PFC suggestive of changes in PFC circuitry. Furthermore, these mice have reduced expression of a key splicing factor, hnRNPA2/B1, which has been previously implicated in synaptic plasticity deficits in $\mathrm{AD}$ (Berson et al., 2012) and in mutations that were recently discovered in rare proteinopathies (Kim et al., 2013). These changes have a functional impact on RNA metabolism in the PFC of VAChT-deficient mice. These re-

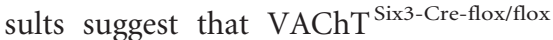
mice may represent a powerful tool to dissect the molecular and neurochemical basis of executive dysfunction.

\section{Cognitive flexibility in}

VAChT ${ }^{\text {Six } 3 \text {-Cre-flox/flox }}$ mice

VAChT ${ }^{\text {Six } 3-C r e-f l o x / f l o x ~}$ mice were able to associate an image with a reward, and another with a punishment, in the pairwise visual discrimination task. Acquisition of this task has been shown to be dependent on glutamatergic signaling, with mice lacking the GLAST glutamate transporter being unable to acquire the task (Karlsson et al., 2009). Evidence suggests that the NMDA receptor is an important molecular switch for the acquisition of the task (Brigman et al., 2008; Barkus et al., 2012). Our results indicate that cholinergic signaling is not required for such learning. In contrast, when contingencies of the pairwise task were reversed, forebrain VAChT knock-out mice were unable to adapt and learn the new rule. Reversal learning in a visual discrimination task has been proposed to serve as a measure of cognitive flexibility in rodents (Izquierdo et al., 2006; Brigman et al., 2008). Neurochemical modulation of reversal learning is complex, as it can be enhanced by targeting multiple neurotransmitter signaling systems including serotonergic (Brigman et al., 2010), dopaminergic (Izquierdo et al., 2006), and glutamatergic (Balschun et al., 2010). The role of cholinergic signaling has been focused predominantly on muscarinic receptors (Ridley et al., 1984, 1985). Determining the exact mechanism has been difficult, as M1 receptor agonists facilitate cognitive flexibility (McCool et al., 2008; Shirey et al., 2009), but no effects on cognitive flexibility were observed in M1-null mice (Bartko et al., 2011). There is evidence suggesting that M2 and M4 receptors may be involved in cognitive flexibility (Nieves-Martinez et al., 2012). Our results indicate that cholinergic signaling is essential for modulation of cognitive flexibility.

\section{Attention deficits in VAChT-deficient mice}

To further understand the role of forebrain ACh in executive function we evaluated attention on forebrain VAChT knock-out mice using the 5-CSRT task, a test suggested to be dependent on PFC cholinergic signaling (Guillem et al., 2011; for review, see Robbins, 2000; Dalley et al., 2004a). In line with our previous
B

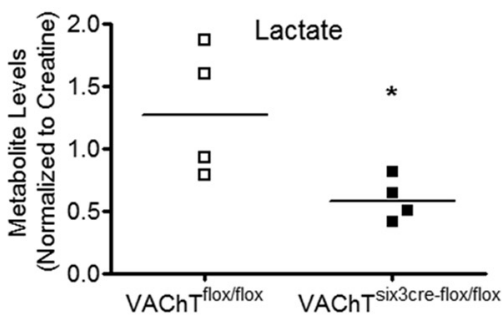

D
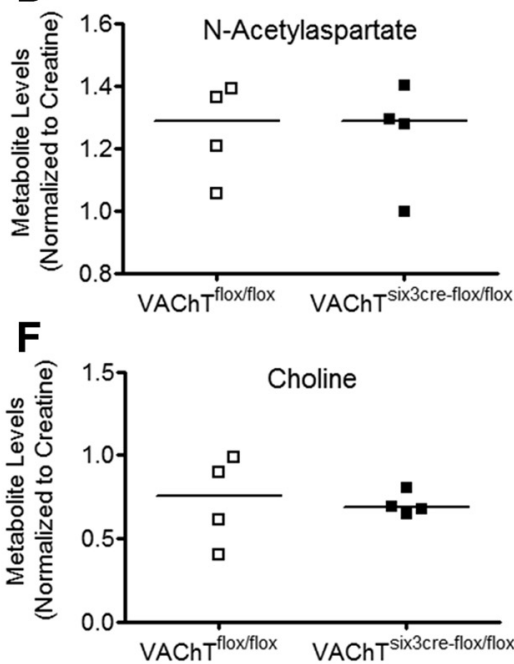

Figure 9. VAChT ${ }^{\text {Six3-Cre-flox/flox }}$ mice have metabolic abnormalities in the PFC. In vivo magnetic resonance spectroscopy of neuronal metabolites. $\boldsymbol{A}, 9.4$ tesla ${ }^{1} \mathrm{H}$ magnetic resonance spectroscopy data from VAChT ${ }^{\text {flox/flox }}$ (top) and VAhT ${ }^{\text {six } 3 \text { cre-flox/flox }}$ component spectra for Tau and Lac are also provided. $\boldsymbol{B}$, Levels of Lac. $\boldsymbol{C}$, Levels of Tau. $\boldsymbol{D}$, Levels of NAA. $\boldsymbol{E}$, Levels of Myo. $\boldsymbol{F}$, Levels of Cho ( $n=4$, data shown are the median and individual values per mouse, ${ }^{*} p<0.05$ ).

finding with the VAChT ${ }^{\text {Six3-Cre-flox/flox }}$ mouse line having learning and memory deficits (Martyn et al., 2012), these mice showed impairments in acquisition of the 5-CSRT, taking nearly twice as long as controls to reach criteria at the 4 and $2 \mathrm{~s}$ phase of the training process. Interestingly, they were not impaired during the pretraining phase, wherein mice are taught to respond to the touchscreen. These results suggest that simple operant conditioning is not dependent on forebrain cholinergic signaling, but rather that forebrain $\mathrm{ACh}$ is responsible for the use of such information to perform higher order cognitive tasks. Attentional demand deficits were probed by reducing stimulus duration. Choice accuracy, perseverative, and premature responses of VAChT ${ }^{\text {Six } 3 \text {-Cre-flox/flox }}$ mice were unaffected. However, the rate of omission for $\mathrm{VAChT}^{\text {Six } 3-C r e-f l o x / f l o x}$ was significantly increased. Additionally, in the presence of a noise distractor $\mathrm{VAChT}^{\text {Six } 3 \text {-Cre-flox/flox }}$ mice were significantly less attentive than controls, showing a much higher rate of omissions. This test was performed under a condition in which the performance of VAChT-deficient mice was on par with controls without the auditory distraction. The auditory distraction task gives a clear indication that the attention deficits observed in VAChT $\mathrm{T}^{\text {Six3-Cre- }}$ flox/flox mice were not due to visual abnormalities. These findings are aligned with previous work, given that cue detection has been shown to involve transient rises in ACh release (Himmelheber et al., 2000; Parikh et al., 2007). Our experiments agree with previous work indicating a key role for cholinergic activity in improv- 


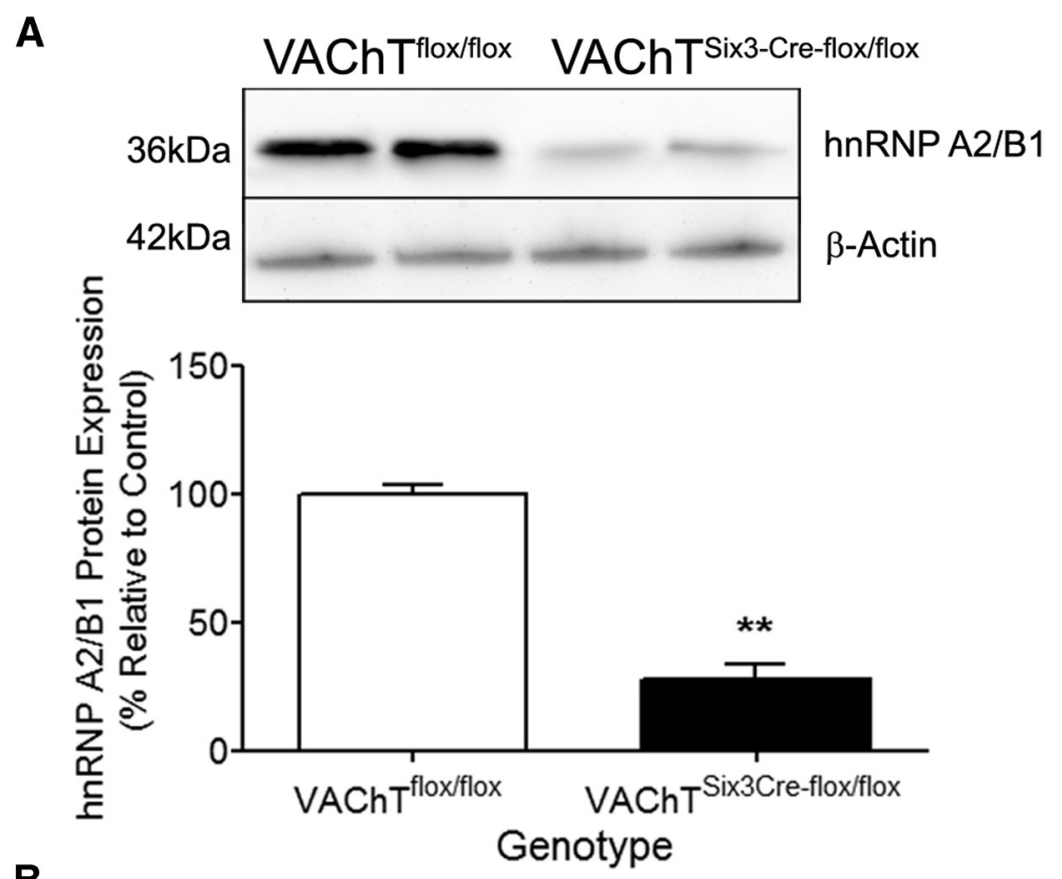

B

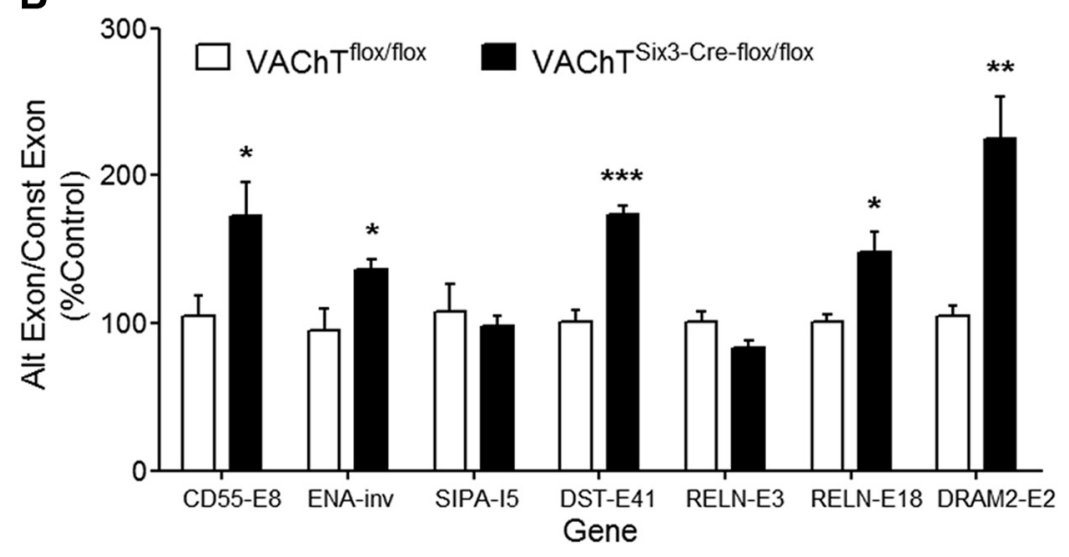

C

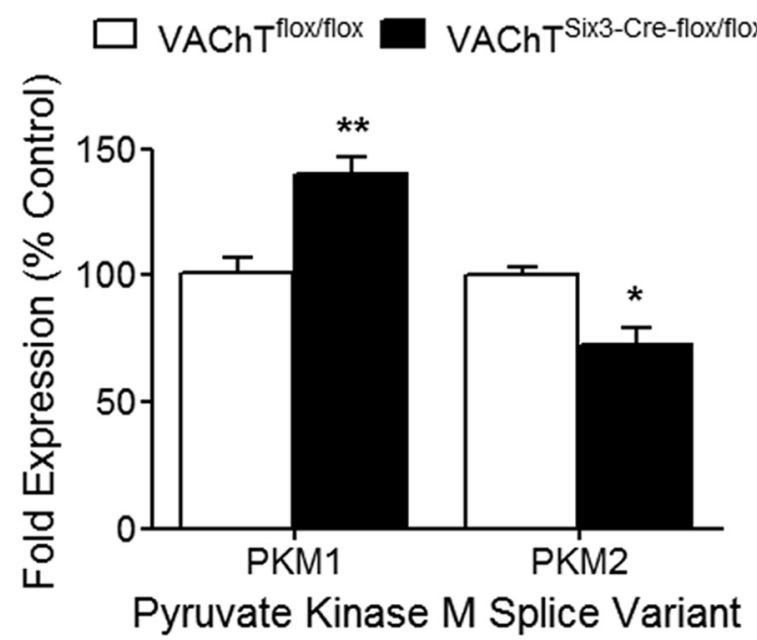

Figure 10. VACh ${ }^{\text {Six3-Cre-flox/flox }}$ mice have abnormal RNA processing in the PFC. $A$, hnRNPA2/B1 protein expression in the PFC with representative immunoblots (inset, $n=4$ ). $B$, qPCR analysis of alternative splicing events for CD55, ENAH, SIPA, Dystonin (DST), Reelin (RELN), and DRAM2. C, Expression of the PKM1 and PKM2 isoforms. Alternative exon levels are normalized to a constitutive exon from the same gene $\left(n=6\right.$, data are mean \pm SEM, ${ }^{*} p<0.05,{ }^{* *} p<0.01$, and $* * * p<0.001)$. ing response to distractors in attentional tasks (Gill et al., 2000; Terry et al., 2002; Newman and McGaughy, 2008; Broussard et al., 2009; Howe et al., 2010; St Peters et al., 2011).

Regulation of attentional performance by endogenous $\mathrm{ACh}$ has been investigated in rats using immunolesion with IgG-192 saporin (Walsh et al., 1996; Risbrough et al., 2002; Lehmann et al., 2003; Chudasama et al., 2004; Dalley et al., 2004b). Specifically, deficits in choice accuracy and increases in perseverative responses were observed in rats following 192 IgG-saporin-induced lesions (McGaughy et al., 2002; Dalley et al., 2004b). In these studies no effects were observed on rates of omissions. Our experiments show a somewhat distinct feature, demonstrating increased rates of omission, without changes in perseverative response. Interestingly, selective elimination of the $\beta 2$ $\mathrm{nAChR}$ in mice also revealed an increase in rate of omissions (Guillem et al., 2011). The differences between genetically modified and lesioned animals could therefore be species related. Alternatively, this difference may reflect the capacity of cholinergic neurons to secrete more than one neurotransmitter (El Mestikawy et al., 2011; Prado et al., 2013). Basal forebrain cholinergic neurons can release glutamate in vitro (Allen et al., 2006). There is also evidence that these neurons possess the machinery to release GABA (Henny and Jones, 2008). Recent experiments targeting striatum cholinergic neurons revealed striking behavioral differences between mice that had cholinergic elimination, using immunolesion, or mice that were genetically targeted to eliminate striatal ACh release (Kitabatake et al., 2003; Guzman et al., 2011; for review, see Prado et al., 2013). Immunolesion of cholinergic neurons can therefore have effects beyond impairing $\mathrm{ACh}$ release and could affect cotransmission. Whether cotransmission has a role in the small phenotypic differences between our experiments and previous work using rats injected with IgG-192saporin remains to be determined.

\section{Alterations in PFC function in VAChT- deficient mice}

Galantamine was unable to rescue the attention deficits in VAChT ${ }^{\text {Six3-Cre-flox/flox }}$ mice. We have previously shown, using a mouse line with decreased VAChT expression, that galantamine could reverse social memory deficits (Prado et al., 2006) and object recognition memory deficits (de Castro et al., 2009b; De Jaeger et al., 2013). Hence, the fact that galantamine can improve performance of control mice, but not of VAChT ${ }^{\text {Six3-Cre-flox/flox }}$ mice, suggests 
that the latter may not release sufficient synaptic ACh to be enhanced by galantamine. Alternatively, these sophisticated tasks may be more affected by changes in neuronal circuitry. The in vivo ${ }^{1} \mathrm{H}$ spectroscopy data suggest that critical metabolic changes occur in VAChT-deficient mice; namely, reduced levels of both Tau and Lac in the prefrontal region. Lac has been proposed as the preferred metabolic substrate for neurons (for review, see Pellerin et al., 2007), suggesting that decreased cholinergic tone may lead to a general decrease in neuronal activity.

The reduction in PFC hnRNPA2/B1 observed in VAChT $\mathrm{T}^{\mathrm{Six} 3-\mathrm{Cre}-\mathrm{flox} / \text { flox }}$ mice is in line with previous work indicating cholinergic-mediated regulation of its expression in $\mathrm{AD}$ (Berson et al., 2012). Furthermore, we found that alternative splicing alteration pattern in the PFC of these mice is similar to the pattern found in both $\mathrm{AD}$ patient samples and hypocholinergic animal models (Berson et al., 2012). Overall, these changes suggest alterations in the PFC circuitry. Furthermore, the splicing change found in the PKM gene indicates a potential mechanism for cholinergic regulation of Lac metabolism. Of note, nearly significant differential expression of the PKM variants was observed in exon array datasets from the entorhinal cortices of three AD patients and three matched controls studied previously, despite the small number of samples (Berson et al., 2012; $p<0.051$; raw data deposited in the GenBank).

Decreased Lac levels have been observed in mouse models of $\mathrm{AD}$ (Du Yan et al., 2000; Marjanska et al., 2005). Moreover, in the CRND8 transgenic mouse model of AD, lower levels of Tau were observed in vivo by $\mathrm{H}^{1}$-NMR (Salek et al., 2010). Interestingly, high levels of Lac in cultured neurons decrease susceptibility to $\mathrm{A} \beta$-derived peptides and oxidative stress in vitro (Newington et al., 2012). Together, these data suggest that VAChT ${ }^{\text {Six3-Cre-flox/flox }}$ mice may be useful for understanding metabolic abnormalities that occur in dementia.

\section{Conclusion}

In summary, by eliminating VAChT from the forebrain we determined that cholinergic signaling regulates executive function, affects metabolism, and also RNA processing in the PFC. The PFC has been shown to mediate salient cue detection (Himmelheber et al., 2000; Parikh et al., 2007), and it serves as a hub that regulates numerous neurotransmitter interactions (Dalley et al., 2004a; Carr et al., 2007; Tait and Brown, 2008). Our work helps to define the specific role played by ACh in behaviors related to cortical functioning, and its potential underlying mechanisms. Decreased levels of VAChT in the brain have been reported in $\mathrm{AD}$ (Efange et al., 1997; Chen et al., 2011), therefore the executive dysfunction and mRNA processing abnormalities we observed in VAChT-deficient mice may be of relevance to model this specific deficiency in humans. Therefore, this work provides novel insights into the basic neurochemical contributors governing executive function.

\section{References}

Allen TG, Abogadie FC, Brown DA (2006) Simultaneous release of glutamate and acetylcholine from single magnocellular "cholinergic" basal forebrain neurons. J Neurosci 26:1588-1595. CrossRef Medline

Alvarez JA, Emory E (2006) Executive function and the frontal lobes: a meta-analytic review. Neuropsychol Rev 16:17-42. CrossRef Medline

Balschun D, Moechars D, Callaerts-Vegh Z, Vermaercke B, Van Acker N, Andries L, D’Hooge R (2010) Vesicular glutamate transporter VGLUT1 has a role in hippocampal long-term potentiation and spatial reversal learning. Cereb Cortex 20:684-693. CrossRef Medline

Barkus C, Feyder M, Graybeal C, Wright T, Wiedholz L, Izquierdo A, Kiselycznyk C, Schmitt W, Sanderson DJ, Rawlins JN, Saksida LM, Bussey TJ, Sprengel R, Bannerman D, Holmes A (2012) Do GluAl knockout mice exhibit behavioral abnormalities relevant to the negative or cognitive symptoms of schizophrenia and schizoaffective disorder? Neuropharmacology 62:1263-1272. CrossRef Medline

Bartha R (2007) Effect of signal-to-noise ratio and spectral linewidth on metabolite quantification at $4 \mathrm{~T}$. NMR Biomed 20:512-521. CrossRef Medline

Bartha R, Drost DJ, Williamson PC (1999) Factors affecting the quantification of short echo in-vivo 1H MR spectra: prior knowledge, peak elimination, and filtering. NMR Biomed 12:205-216. CrossRef Medline

Bartha R, Drost DJ, Menon RS, Williamson PC (2000a) Comparison of the quantification precision of human short echo time (1)H spectroscopy at 1.5 and 4.0 Tesla. Magn Reson Med 44:185-192. CrossRef Medline

Bartha R, Drost DJ, Menon RS, Williamson PC (2000b) Spectroscopic lineshape correction by QUECC: combined QUALITY deconvolution and eddy current correction. Magn Reson Med 44:641-645. CrossRef Medline

Bartha R, Smith M, Rupsingh R, Rylett J, Wells JL, Borrie MJ (2008) High field (1)H MRS of the hippocampus after donepezil treatment in Alzheimer disease. Prog Neuropsychopharmacol Biol Psychiatry 32:786-793. CrossRef Medline

Bartko SJ, Romberg C, White B, Wess J, Bussey TJ, Saksida LM (2011) Intact attentional processing but abnormal responding in M1 muscarinic receptor-deficient mice using an automated touchscreen method. Neuropharmacology 61:1366-1378. CrossRef Medline

Berson A, Barbash S, Shaltiel G, Goll Y, Hanin G, Greenberg DS, Ketzef M, Becker AJ, Friedman A, Soreq H (2012) Cholinergic-associated loss of hnRNP-A/B in Alzheimer's disease impairs cortical splicing and cognitive function in mice. EMBO Mol Med 4:730-742. CrossRef Medline

Brigman JL, Feyder M, Saksida LM, Bussey TJ, Mishina M, Holmes A (2008) Impaired discrimination learning in mice lacking the NMDA receptor NR2A subunit. Learn Mem 15:50-54. CrossRef Medline

Brigman JL, Mathur P, Harvey-White J, Izquierdo A, Saksida LM, Bussey TJ, Fox S, Deneris E, Murphy DL, Holmes A (2010) Pharmacological or genetic inactivation of the serotonin transporter improves reversal learning in mice. Cereb Cortex 20:1955-1963. CrossRef Medline

Broussard JI, Karelina K, Sarter M, Givens B (2009) Cholinergic optimization of cue-evoked parietal activity during challenged attentional performance. Eur J Neurosci 29:1711-1722. CrossRef Medline

Carr DB, Andrews GD, Glen WB, Lavin A (2007) alpha2-Noradrenergic receptors activation enhances excitability and synaptic integration in rat prefrontal cortex pyramidal neurons via inhibition of HCN currents. J Physiol 584:437-450. CrossRef Medline

Chen GJ, Xiong Z, Yan Z (2013) Abeta impairs nicotinic regulation of inhibitory synaptic transmission and interneuron excitability in prefrontal cortex. Mol Neurodegener 8:3. CrossRef Medline

Chen KH, Reese EA, Kim HW, Rapoport SI, Rao JS (2011) Disturbed neurotransmitter transporter expression in Alzheimer's disease brain. J Alzheimers Dis 26:755-766. Medline

Chen M, Zhang J, Manley JL (2010) Turning on a fuel switch of cancer: hnRNP proteins regulate alternative splicing of pyruvate kinase mRNA. Cancer Res 70:8977-8980. CrossRef Medline

Chudasama Y (2011) Animal models of prefrontal-executive function. Behav Neurosci 125:327-343. CrossRef Medline

Chudasama Y, Dalley JW, Nathwani F, Bouger P, Robbins TW (2004) Cholinergic modulation of visual attention and working memory: dissociable effects of basal forebrain 192-IgG-saporin lesions and intraprefrontal infusions of scopolamine. Learn Mem 11:78-86. CrossRef Medline

Clower CV, Chatterjee D, Wang Z, Cantley LC, Vander Heiden MG, Krainer AR (2010) The alternative splicing repressors hnRNP A1/A2 and PTB influence pyruvate kinase isoform expression and cell metabolism. Proc Natl Acad Sci U S A 107:1894-1899. CrossRef Medline

Dalley JW, Cardinal RN, Robbins TW (2004a) Prefrontal executive and cognitive functions in rodents: neural and neurochemical substrates. Neurosci Biobehav Rev 28:771-784. CrossRef Medline

Dalley JW, Theobald DE, Bouger P, Chudasama Y, Cardinal RN, Robbins TW (2004b) Cortical cholinergic function and deficits in visual attentional performance in rats following $192 \mathrm{IgG}$-saporin-induced lesions of the medial prefrontal cortex. Cereb Cortex 14:922-932. CrossRef Medline

David CJ, Chen M, Assanah M, Canoll P, Manley JL (2010) HnRNP proteins controlled by c-Myc deregulate pyruvate kinase mRNA splicing in cancer. Nature 463:364-368. CrossRef Medline

de Castro BM, De Jaeger X, Martins-Silva C, Lima RD, Amaral E, Menezes C, Lima P, Neves CM, Pires RG, Gould TW, Welch I, Kushmerick C, Gua- 
timosim C, Izquierdo I, Cammarota M, Rylett RJ, Gomez MV, Caron MG, Oppenheim RW, Prado MA, et al. (2009a) The vesicular acetylcholine transporter is required for neuromuscular development and function. Mol Cell Biol 29:5238-5250. CrossRef Medline

de Castro BM, Pereira GS, Magalhães V, Rossato JI, De Jaeger X, MartinsSilva C, Leles B, Lima P, Gomez MV, Gainetdinov RR, Caron MG, Izquierdo I, Cammarota M, Prado VF, Prado MA (2009b) Reduced expression of the vesicular acetylcholine transporter causes learning deficits in mice. Genes Brain Behav 8:23-35. CrossRef Medline

De Jaeger X, Cammarota M, Prado MA, Izquierdo I, Prado VF, Pereira GS (2013) Decreased acetylcholine release delays the consolidation of object recognition memory. Behav Brain Res 238:62-68. CrossRef Medline

DelaBarre L, Garwood M (1998) LASER: adiabatic single shot localization with J-refocUsing. Proceedings of the International Society of Magnetic Resonance in Medicine:358.

Du Yan S, Zhu Y, Stern ED, Hwang YC, Hori O, Ogawa S, Frosch MP, Connolly ES Jr, McTaggert R, Pinsky DJ, Clarke S, Stern DM, Ramasamy $\mathrm{R}$ (2000) Amyloid beta-peptide-binding alcohol dehydrogenase is a component of the cellular response to nutritional stress. J Biol Chem 275:27100-27109. Medline

Efange SM, Garland EM, Staley JK, Khare AB, Mash DC (1997) Vesicular acetylcholine transporter density and Alzheimer's disease. Neurobiol Aging 18:407-413. CrossRef Medline

Elliott R (2003) Executive functions and their disorders: imaging in clinical neuroscience. Br Med Bull 65:49-59. CrossRef Medline

El Mestikawy S, Wallén-Mackenzie A, Fortin GM, Descarries L, Trudeau LE (2011) From glutamate co-release to vesicular synergy: vesicular glutamate transporters. Nat Rev Neurosci 12:204-216. CrossRef Medline

Evers EA, van der Veen FM, Fekkes D, Jolles J (2007) Serotonin and cognitive flexibility: neuroimaging studies into the effect of acute tryptophan depletion in healthy volunteers. Curr Med Chem 14:2989-2995. CrossRef Medline

Gill TM, Sarter M, Givens B (2000) Sustained visual attention performanceassociated prefrontal neuronal activity: evidence for cholinergic modulation. J Neurosci 20:4745-4757. Medline

Graybeal C, Feyder M, Schulman E, Saksida LM, Bussey TJ, Brigman JL, Holmes A (2011) Paradoxical reversal learning enhancement by stress or prefrontal cortical damage: rescue with BDNF. Nat Neurosci 14:15071509. CrossRef Medline

Grottick AJ, Higgins GA (2000) Effect of subtype selective nicotinic compounds on attention as assessed by the five-choice serial reaction time task. Behav Brain Res 117:197-208. CrossRef Medline

Guillem K, Bloem B, Poorthuis RB, Loos M, Smit AB, Maskos U, Spijker S, Mansvelder HD (2011) Nicotinic acetylcholine receptor beta2 subunits in the medial prefrontal cortex control attention. Science 333:888-891. CrossRef Medline

Guzman MS, De Jaeger X, Raulic S, Souza IA, Li AX, Schmid S, Menon RS, Gainetdinov RR, Caron MG, Bartha R, Prado VF, Prado MA (2011) Elimination of the vesicular acetylcholine transporter in the striatum reveals regulation of behaviour by cholinergic-glutamatergic co-transmission. PLoS Biol 9:e1001194. CrossRef Medline

Hasselmo ME, Sarter M (2011) Modes and models of forebrain cholinergic neuromodulation of cognition. Neuropsychopharmacology 36:52-73. CrossRef Medline

Henny P, Jones BE (2008) Projections from basal forebrain to prefrontal cortex comprise cholinergic, GABAergic and glutamatergic inputs to pyramidal cells or interneurons. Eur J Neurosci 27:654-670. CrossRef Medline

Hill EL (2004) Executive dysfunction in autism. Trends Cogn Sci 8:26-32. CrossRef Medline

Himmelheber AM, Sarter M, Bruno JP (2000) Increases in cortical acetylcholine release during sustained attention performance in rats. Brain Res Cogn Brain Res 9:313-325. CrossRef Medline

Hoek KS, Kidd GJ, Carson JH, Smith R (1998) hnRNP A2 selectively binds the cytoplasmic transport sequence of myelin basic protein mRNA. Biochemistry 37:7021-7029. CrossRef Medline

Howe WM, Ji J, Parikh V, Williams S, Mocaër E, Trocmé-Thibierge C, Sarter M (2010) Enhancement of attentional performance by selective stimulation of alpha4beta2 $\left(^{*}\right)$ nAChRs: underlying cholinergic mechanisms. Neuropsychopharmacology 35:1391-1401. CrossRef Medline

Izquierdo A, Wiedholz LM, Millstein RA, Yang RJ, Bussey TJ, Saksida LM, Holmes A (2006) Genetic and dopaminergic modulation of reversal learning in a touchscreen-based operant procedure for mice. Behav Brain Res 171:181-188. CrossRef Medline

Jurado MB, Rosselli M (2007) The elusive nature of executive functions: a review of our current understanding. Neuropsychol Rev 17:213-233. CrossRef Medline

Kamma H, Horiguchi H, Wan L, Matsui M, Fujiwara M, Fujimoto M, Yazawa T, Dreyfuss G (1999) Molecular characterization of the hnRNP A2/B1 proteins: tissue-specific expression and novel isoforms. Exp Cell Res 246: 399-411. CrossRef Medline

Karlsson RM, Tanaka K, Saksida LM, Bussey TJ, Heilig M, Holmes A (2009) Assessment of glutamate transporter GLAST (EAAT1)-deficient mice for phenotypes relevant to the negative and executive/cognitive symptoms of schizophrenia. Neuropsychopharmacology 34:1578-1589. Medline

Kassem MN, Bartha R (2003) Quantitative proton short-echo-time LASER spectroscopy of normal human white matter and hippocampus at 4 tesla incorporating macromolecule subtraction. Magn Reson Med 49:918-927. CrossRef Medline

Kim HJ, Kim NC, Wang YD, Scarborough EA, Moore J, Diaz Z, MacLea KS, Freibaum B, Li S, Molliex A, Kanagaraj AP, Carter R, Boylan KB, Wojtas AM, Rademakers R, Pinkus JL, Greenberg SA, Trojanowski JQ, Traynor BJ, Smith BN, et al. (2013) Mutations in prion-like domains in hnRNPA2B1 and hnRNPA1 cause multisystem proteinopathy and ALS. Nature 495:467-473. CrossRef Medline

Kitabatake Y, Hikida T, Watanabe D, Pastan I, Nakanishi S (2003) Impairment of reward-related learning by cholinergic cell ablation in the striatum. Proc Natl Acad Sci U S A 100:7965-7970. CrossRef Medline

Kolisnyk B, Guzman MS, Raulic S, Fan J, Magalhães AC, Feng G, Gros R, Prado VF, Prado MA (2013) ChAT-ChR2-EYFP mice have enhanced motor endurance but show deficits in attention and several additional cognitive domains. J Neurosci 33:10427-10438. CrossRef Medline

Lehmann O, Grottick AJ, Cassel JC, Higgins GA (2003) A double dissociation between serial reaction time and radial maze performance in rats subjected to $192 \mathrm{IgG}$-saporin lesions of the nucleus basalis and/or the septal region. Eur J Neurosci 18:651-666. CrossRef Medline

Marjanska M, Curran GL, Wengenack TM, Henry PG, Bliss RL, Poduslo JF, Jack CR Jr, Ugurbil K, Garwood M (2005) Monitoring disease progression in transgenic mouse models of Alzheimer's disease with proton magnetic resonance spectroscopy. Proc Natl Acad Sci U S A 102:1190611910. CrossRef Medline

Martins-Silva C, De Jaeger X, Guzman MS, Lima RD, Santos MS, Kushmerick C, Gomez MV, Caron MG, Prado MA, Prado VF (2011) Novel strains of mice deficient for the vesicular acetylcholine transporter: insights on transcriptional regulation and control of locomotor behavior. PLoS One 6:e17611. CrossRef Medline

Martyn AC, De Jaeger X, Magalhães AC, Kesarwani R, Gonçalves DF, Raulic S, Guzman MS, Jackson MF, Izquierdo I, Macdonald JF, Prado MA, Prado VF (2012) Elimination of the vesicular acetylcholine transporter in the forebrain causes hyperactivity and deficits in spatial memory and long-term potentiation. Proc Natl Acad Sci U S A 109:17651-17656. CrossRef Medline

McCool MF, Patel S, Talati R, Ragozzino ME (2008) Differential involvement of M1-type and M4-type muscarinic cholinergic receptors in the dorsomedial striatum in task switching. Neurobiol Learn Mem 89:114124. CrossRef Medline

McGaughy J, Decker MW, Sarter M (1999) Enhancement of sustained attention performance by the nicotinic acetylcholine receptor agonist ABT418 in intact but not basal forebrain-lesioned rats. Psychopharmacology 144:175-182. CrossRef Medline

McGaughy J, Dalley JW, Morrison CH, Everitt BJ, Robbins TW (2002) Selective behavioral and neurochemical effects of cholinergic lesions produced by intrabasalis infusions of 192 IgG-saporin on attentional performance in a five-choice serial reaction time task. J Neurosci 22:19051913. Medline

McGuinness B, Barrett SL, Craig D, Lawson J, Passmore AP (2010) Executive functioning in Alzheimer's disease and vascular dementia. Int J Geriatr Psychiatry 25:562-568. Medline

Morice R (1990) Cognitive inflexibility and pre-frontal dysfunction in schizophrenia and mania. Br J Psychiatry 157:50-54. CrossRef Medline

Newington JT, Rappon T, Albers S, Wong DY, Rylett RJ, Cumming RC (2012) Overexpression of pyruvate dehydrogenase kinase 1 and lactate dehydrogenase A in nerve cells confers resistance to amyloid beta and 
other toxins by decreasing mitochondrial respiration and reactive oxygen species production. J Biol Chem 287:37245-37258. CrossRef Medline

Newman LA, McGaughy J (2008) Cholinergic deafferentation of prefrontal cortex increases sensitivity to cross-modal distractors during a sustained attention task. J Neurosci 28:2642-2650. CrossRef Medline

Nieves-Martinez E, Haynes K, Childers SR, Sonntag WE, Nicolle MM (2012) Muscarinic receptor/G-protein coupling is reduced in the dorsomedial striatum of cognitively impaired aged rats. Behav Brain Res 227:258-264. CrossRef Medline

Parikh V, Ji J, Decker MW, Sarter M (2010) Prefrontal beta2 subunitcontaining and alpha7 nicotinic acetylcholine receptors differentially control glutamatergic and cholinergic signaling. J Neurosci 30:3518-3530. CrossRef Medline

Parikh V, Kozak R, Martinez V, Sarter M (2007) Prefrontal acetylcholine release controls cue detection on multiple timescales. Neuron 56:141154. CrossRef Medline

Pellerin L, Bouzier-Sore AK, Aubert A, Serres S, Merle M, Costalat R, Magistretti PJ (2007) Activity-dependent regulation of energy metabolism by astrocytes: an update. Glia 55:1251-1262. CrossRef Medline

Perry EK, Gibson PH, Blessed G, Perry RH, Tomlinson BE (1977) Neurotransmitter enzyme abnormalities in senile dementia. Choline acetyltransferase and glutamic acid decarboxylase activities in necropsy brain tissue. J Neurol Sci 34:247-265. CrossRef Medline

Perry RJ, Hodges JR (1999) Attention and executive deficits in Alzheimer's disease: a critical review. Brain 122:383-404. CrossRef Medline

Pfeuffer J, Tkác I, Provencher SW, Gruetter R (1999) Toward an in vivo neurochemical profile: quantification of 18 metabolites in short-echotime (1)H NMR spectra of the rat brain. J Magn Reson 141:104-120. CrossRef Medline

Prado VF, Martins-Silva C, de Castro BM, Lima RF, Barros DM, Amaral E, Ramsey AJ, Sotnikova TD, Ramirez MR, Kim HG, Rossato JI, Koenen J, Quan H, Cota VR, Moraes MF, Gomez MV, Guatimosim C, Wetsel WC, Kushmerick C, Pereira GS, et al. (2006) Mice deficient for the vesicular acetylcholine transporter are myasthenic and have deficits in object and social recognition. Neuron 51:601-612. CrossRef Medline

Prado VF, Roy A, Kolisnyk B, Gros R, Prado MA (2013) Regulation of cholinergic activity by the vesicular acetylcholine transporter. Biochem J 450: 265-274. CrossRef Medline

Ridley RM, Barratt NG, Baker HF (1984) Cholinergic learning deficits in the marmoset produced by scopolamine and ICV hemicholinium. Psychopharmacology 83:340-345. CrossRef Medline

Ridley RM, Baker HF, Drewett B, Johnson JA (1985) Effects of ibotenic acid lesions of the basal forebrain on serial reversal learning in marmosets. Psychopharmacology 86:438-443. CrossRef Medline

Risbrough V, Bontempi B, Menzaghi F (2002) Selective immunolesioning of the basal forebrain cholinergic neurons in rats: effect on attention using the 5-choice serial reaction time task. Psychopharmacology 164:71-81. CrossRef Medline

Robbins TW (2000) From arousal to cognition: the integrative position of the prefrontal cortex. Prog Brain Res 126:469-483. CrossRef Medline

Robbins TW (2002) The 5-choice serial reaction time task: behavioural pharmacology and functional neurochemistry. Psychopharmacology 163:362-380. CrossRef Medline

Robbins TW, Roberts AC (2007) Differential regulation of fronto-executive function by the monoamines and acetylcholine. Cereb Cortex 17 ]Suppl 1[:i151-160. Medline

Romberg C, Horner AE, Bussey TJ, Saksida LM (2013) A touch screenautomated cognitive test battery reveals impaired attention, memory ab- normalities, and increased response inhibition in the TgCRND8 mouse model of Alzheimer's disease. Neurobiol Aging 34:731-744. CrossRef Medline

Romberg C, Mattson MP, Mughal MR, Bussey TJ, Saksida LM (2011) Impaired attention in the $3 \mathrm{x}$ TgAD mouse model of Alzheimer's disease: rescue by donepezil (Aricept). J Neurosci 31:3500-3507. CrossRef Medline

Sala M, Braida D, Lentini D, Busnelli M, Bulgheroni E, Capurro V, Finardi A, Donzelli A, Pattini L, Rubino T, Parolaro D, Nishimori K, Parenti M, Chini B (2011) Pharmacologic rescue of impaired cognitive flexibility, social deficits, increased aggression, and seizure susceptibility in oxytocin receptor null mice: a neurobehavioral model of autism. Biol Psychiatry 69:875-882. CrossRef Medline

Salek RM, Xia J, Innes A, Sweatman BC, Adalbert R, Randle S, McGowan E, Emson PC, Griffin JL (2010) A metabolomic study of the CRND8 transgenic mouse model of Alzheimer's disease. Neurochem Int 56:937-947. CrossRef Medline

Sarter M, Givens B, Bruno JP (2001) The cognitive neuroscience of sustained attention: where top-down meets bottom-up. Brain Res Brain Res Rev 35:146-160. CrossRef Medline

Schmitt JA, Wingen M, Ramaekers JG, Evers EA, Riedel WJ (2006) Serotonin and human cognitive performance. Curr Pharm Des 12:2473-2486. CrossRef Medline

Shirey JK, Brady AE, Jones PJ, Davis AA, Bridges TM, Kennedy JP, Jadhav SB, Menon UN, Xiang Z, Watson ML, Christian EP, Doherty JJ, Quirk MC, Snyder DH, Lah JJ, Levey AI, Nicolle MM, Lindsley CW, Conn PJ (2009) A selective allosteric potentiator of the M1 muscarinic acetylcholine receptor increases activity of medial prefrontal cortical neurons and restores impairments in reversal learning. J Neurosci 29:14271-14286. CrossRef Medline

Stalnaker TA, Takahashi Y, Roesch MR, Schoenbaum G (2009) Neural substrates of cognitive inflexibility after chronic cocaine exposure. Neuropharmacology 56, [Supplement 1]:63-72. CrossRef Medline

St Peters M, Demeter E, Lustig C, Bruno JP, Sarter M (2011) Enhanced control of attention by stimulating mesolimbic-corticopetal cholinergic circuitry. J Neurosci 31:9760-9771. CrossRef Medline

Tait DS, Brown VJ (2008) Lesions of the basal forebrain impair reversal learning but not shifting of attentional set in rats. Behav Brain Res 187: 100-108. CrossRef Medline

Terry AV Jr, Risbrough VB, Buccafusco JJ, Menzaghi F (2002) Effects of (+/-)-4-[[2-(1-methyl-2-pyrrolidinyl)ethyl]thio]phenol hydrochloride (SIB-1553A), a selective ligand for nicotinic acetylcholine receptors, in tests of visual attention and distractibility in rats and monkeys. J Pharmacol Exp Ther 301:284-292. CrossRef Medline

Traykov L, Raoux N, Latour F, Gallo L, Hanon O, Baudic S, Bayle C, Wenisch E, Remy P, Rigaud AS (2007) Executive functions deficit in mild cognitive impairment. Cogn Behav Neurol 20:219-224. CrossRef Medline

Walsh TJ, Herzog CD, Gandhi C, Stackman RW, Wiley RG (1996) Injection of IgG 192-saporin into the medial septum produces cholinergic hypofunction and dose-dependent working memory deficits. Brain Res 726: 69-79. CrossRef Medline

Whitehouse PJ, Price DL, Clark AW, Coyle JT, DeLong MR (1981) Alzheimer disease: evidence for selective loss of cholinergic neurons in the nucleus basalis. Ann Neurol 10:122-126. CrossRef Medline

Whitehouse PJ, Price DL, Struble RG, Clark AW, Coyle JT, Delon MR (1982) Alzheimer's disease and senile dementia: loss of neurons in the basal forebrain. Science 215:1237-1239. CrossRef Medline 